\title{
The Role of Law, Corruption and Culture in Investment Fund Manager Fees*
}

\author{
Sofia A. Johan \\ TILEC/AFM Senior Research Fellow \\ Tilburg Law and Economics Center \\ Postbus 90153 \\ 5000 LE Tilburg \\ The Netherlands \\ Email: sofiajohan@email.com \\ Dorra Najar \\ University Paris-Dauphine \\ Place du Marechal de Lattre de Tassigny, \\ 75775 PARIS Cedex 16 (France) \\ Email: dorra.najar@dauphine.fr
}

Draft in Progress: May 26, 2010

\footnotetext{
* We owe thanks to Douglas Cumming for helpful comments and suggestions. As well, we are grateful to a number of fund managers from around the world in sharing their confidential data on fund structures and compensation terms.
} 


\title{
The Role of Law, Corruption and Culture in Investment Fund Manager Fees
}

\author{
Draft in Progress: May 26, 2010
}

\begin{abstract}
This paper considers an international sample of venture capital and private equity funds to assess the role of law, corruption and culture in setting fund manager fees in terms of their fixed management fees, carried interest performance fees, clawbacks of fees and cash versus share distributions of fees. The data highlight a role of legal conditions in shaping fees paid to fund managers. In countries with better legal conditions, fixed fees are lower, carried interest fees are higher, clawbacks are less likely, and share distributions are more likely. These findings suggest legal conditions help to align the interests of managers and shareholders. More specifically, we examine which element of legal conditions matter most, and discover that corruption levels play a pronounced role in shaping fund manager fee contracts. We also show that cultural forces such as Hofstede`s measures of power distance and uncertainty avoidance likewise play a role in influencing fees.
\end{abstract}

Keywords: Managerial Compensation; Incentive Contracts, Private Equity; Law and Finance

JEL Codes: G23, G24, G28, K22, K34 


\section{Introduction}

Over the course of the mid-2007-2009 financial crisis, fees paid to financial managers have been rigorously scrutinized. There are numerous examples that have become notorious, largely associated with government bailouts and subsequent bonus payments. For example, Sir Fred Goodwin, the former CEO of the Bank of Scotland, received fees that led The Economist to refer to him as "dishonorable". ${ }^{1}$ There are blogs that cite a deathwatch for Sir Fred Goodwin, ${ }^{2}$ just as there were numerous reports of death threats for AIG employees after their bonus payments subsequent to government bailouts. ${ }^{3}$ Credit Suisse approved in April 2010 very controversial bonus payments. ${ }^{4}$ Similar examples are extremely widespread that it is hard to not make the mental connection between regulation, corruption, ethics and fees in the financial community.

Likewise, there has been a significant and growing concern in the venture capital and private equity industries worldwide has been the presence of corruption in influencing fund manager activities. For example, the law firm S.J. Berwin noted in their Private Equity Comment ${ }^{5}$ (March 2010) that:

Private equity funds, as "active" owners of international businesses, can also be a deep pocketed, high profile target for prosecutors looking for someone to bring to book in the wake of a corruption investigation involving a portfolio company. Furthermore, the 2009 Report on Progress on the UNPRI showed that $46 \%$ of asset owners and $36.2 \%$ of investment managers who had signed up to the Principles cited bribery and corruption as "Environmental, Social and Governance" issues" which they addressed when engaging with service providers. It makes good business sense, therefore, for managers to understand the legal issues in every country in which the fund does business, and to take active steps to ensure that responsible business practices are adopted throughout the portfolio.

S.J. Berwin further commented that the private equity industry worldwide would suffer from the longer term effects from the crackdown on corruption for many years to come. S.J. Berwin expressed particular concern with international private equity transactions and exposure to firms linked to governments and corruption:

The case of Vetco Gray UK (which was acquired along with its German parent by a consortium of three private equity firms) is a salutary lesson. Here it was discovered that

${ }^{1}$ http://www.economist.com/research/articlesBySubject/displayStory.cfm?story_ID=13235025\&subj ectid=987105

$\frac{}{2} \mathrm{http://seekingalpha.com/article/78111-royal-bank-of-scotland-ceo-deathwatch}$

3 http://en.wikipedia.org/wiki/American_International_Group

${ }^{4}$ http://www.swissinfo.ch/eng/business/Credit_Suisse_avoids_shareholder_bonus_revolt.html?cid=8 785404

${ }^{5}$ http://www.sjberwin.com/latestpublicationdetails.aspx?title=privateequitycomment 
bribes had been paid to Nigerian government officials in relation to oil exploration projects. This resulted not only in a record fine by the US Department of Justice of $\$ 12$ million for Vetco Gray UK (which had collectively authorised the payments with several of its affiliates) but also the imposition of an independent monitor (at the company's expense) and further investigation of the company's activities in other countries, which became binding on any future purchaser of the company... Naturally, any areas identified as high-risk countries or industries should be treated with care, as should business dealings with statelinked enterprises and supranational bodies.

This wave of media coverage and public outrage against fund manager fees in recent years suggests a need to better understand the determinants of fund manager fees. Fund manager fees comprise many components, including fixed fees, performance based fees, clawbacks, and cash versus share payments.

The fees contracts for fund managers of venture capital and private equity managers are no exception, and thus provide a useful context in which to examine the role of law, corruption and culture in setting fund manager fees. Venture capital and private equity funds are typically set up as limited partnerships whereby the institutional investors are the limited partners and the fund manager is the general partner (Cumming et al., 2005). Institutional investors include pension funds (Jeng and Wells, 2000; Mayer et al., 2004) (which are most common across countries), insurance companies, banks and endowments, etc. Private investment funds typically have a finite life of 10-13 years. This life-span enables the fund time to select appropriate investees and carry out such investments to fruition. A typical investment in an entrepreneurial firm can take from 2-7 years from first investment to the exit date. Entrepreneurial firms typically lack income, revenue and/or cash flows to pay interest on debt and dividends on equity; hence, returns to institutional investors are in the form of capital gains upon exit (such as an IPO or acquisition for successful entrepreneurial firms, or a write-off for unsuccessful firms).

Private fund managers are compensated with a two-part fee. The first part is a fixed fee which is commonly 1-3\% of the fund's assets in the U.S. (Gompers and Lerner, 1999a, b), and paid per year. This enables an appropriate annual salary for the fund managers and enables the fund managers to meet overhead costs over the life-span of the fund, particularly in times prior to the realization of investments in the investee firms. The second component is the performance fee, or carried interest, which is commonly $20 \%$ of the profits earned by successful fund investments (Gompers and Lerner, 1999a,b). Fixed fees are higher and performance fees are lower among younger funds, which is consistent 
with a learning model whereby risk adverse fund managers are more likely to prefer more certain compensation when their abilities are unknown to themselves (Gompers and Lerner, 1999a, 1999b). Fund managers may face clawbacks from their fees, which means that institutional investors in funds can reduce fees in the event of poor performance. Institutional investors into funds can state in limited partnership contracts that payment terms come in the form of cash or share distributions.

In this paper we compare and contrast the role of fund manager characteristics and market conditions to the legal and institutional setting in which a fund is based to understand the determinants of fund manager fees. We expect market conditions and fund manager characteristics to be important in setting fees, as these factors would be important in any labor market context. In respect of legal and institutional differences, we compare and contrast the role of legal conditions versus cultural conditions in a country to ascertain the importance of country-specific factors on fees. We expect countries with superior legal settings to affect fees in a way that better aligns the interests of fund managers with their investors, as shown in prior work with a sample of 50 venture capital funds worldwide (Cumming and Johan, 2009). We extend prior work in two important dimensions. First, we obtain a much larger and more recent sample to assess the robustness of prior findings. Second, and perhaps more importantly, we explore for the first time the effect of the specific features of a country's legal and institutional setting on fees, including different components of legal conditions (specific indices from La Porta et al. 1998) as well as cultural dimensions on fees (Hofstede's cultural indices).

Based on a sample of 123 venture capital and private equity funds around the world, we find that in countries with better legal conditions, fixed fees are lower, carried interest fees are higher, clawbacks are less likely, and share distributions are more likely. These findings support the idea that legal conditions help to align the interests of managers and shareholders. We extend our empirical analyses to ascertain what specific legal conditions matter across countries. We find that corruption levels play a pronounced role in shaping fund manager fee contracts across countries. For example, corruption is the only significant legal determinant of setting fixed fees such that fixed fees are lower in less corrupt countries. We also show that cultural forces such as Hofstede`s measures of power distance and uncertainty avoidance likewise play a role in influencing fees. Overall, it is noteworthy that laws and culture are much more significant in determining fees than fund manager characteristics and/or market conditions. 
Our paper is related to a growing the literature on law and finance associated with financial intermediation. Prior work has shown that fees depend on legal conditions (Cumming and Johan, 2009) but the dearth of data in that work with 50 observations led to inconclusive statements about what specifically matters in terms of specific attributes of a legal system that affects fees. Other related evidence has shown legal systems affect venture capital financial contracts with entrepreneurs and investment performance (Lerner and Schoar, 2005; Hege et al., 2009; Cumming and Johan, 2009), as do cultural factors across countries (Hazarika et al., 2009). Our paper contributes to the literature by examining how specific legal and cultural differences across countries matter for fee structures.

This paper is organized as follows. Section 2 considers the institutional context and develops hypotheses pertaining to the determinants of fees. The data and summary statistics are presented in section 3. Empirical tests follow in section 4. Concluding remarks are provided in the last section.

\section{Hypotheses}

In subsection 2.1 we first briefly outline predictions in regards to the relation between legal conditions and managerial compensation. Thereafter in subsection 2.2 we discuss the importance of certain control variables.

\subsection{Law, Culture and Fund Manager Compensation}

Private fund managers are financial intermediaries between institutional investors and entrepreneurial firms. Institutional investors do not have the time and specialized skill set to carry out due diligence in screening potential private entrepreneurial firms in which to invest; institutional investors also do not have the time and skills to efficiently monitor and add value to the investee entrepreneurial firms. The pronounced risks, information asymmetries and agency problems associated with investments in small, illiquid, and hightech entrepreneurial firms is a primary explanation for the existence of private investment funds with specialized skill sets to mitigate such problems (Sahlman, 1990; Gompers and Lerner, 1999a,b).

We expect countries with superior legal settings to affect fees in a way that better

aligns the interests of fund managers with their investors. Legal conditions can be measured in a variety of ways, such as the many indices developed by La Porta et al. 
(1998) and others. The traditional La Porta et al. (1998) indices include efficiency of judicial system, rule of law, corruption, risk of expropriation, risk of contract repudiation, and shareholder rights. A weighted average of these indices was adopted by Berkowitz et al. (2003), and referred to as the Legality Index. It is natural to expect these indices to matter for cross-country determinants in fees, not because these indices were developed for limited partnerships, but rather because they affect the uncertainty faced by fund managers in carrying out their investments in those countries and as such their expected incomes.

Similarly, as fee contracts are the outcome of bargaining between fund managers and their institutional investors, and bargaining depends on culture in different countries, we may expect cultural measures developed by Hofstede to matter in setting fees. These cultural dimensions are as follows: ${ }^{6}$

Power Distance Index (PDI) that is the extent to which the less powerful members of organizations and institutions (like the family) accept and expect that power is distributed unequally. This represents inequality (more versus less), but defined from below, not from above. It suggests that a society's level of inequality is endorsed by the followers as much as by the leaders. Power and inequality, of course, are extremely fundamental facts of any society and anybody with some international experience will be aware that 'all societies are unequal, but some are more unequal than others'.

Individualism (IDV) on the one side versus its opposite, collectivism, that is the degree to which individuals are integrated into groups. On the individualist side we find societies in which the ties between individuals are loose: everyone is expected to look after him/herself and his/her immediate family. On the collectivist side, we find societies in which people from birth onwards are integrated into strong, cohesive in-groups, often extended families (with uncles, aunts and grandparents) which continue protecting them in exchange for unquestioning loyalty. The word 'collectivism' in this sense has no political meaning: it refers to the group, not to the state. Again, the issue addressed by this dimension is an extremely fundamental one, regarding all societies in the world.

Masculinity (MAS) versus its opposite, femininity, refers to the distribution of roles between the genders which is another fundamental issue for any society to which a range of solutions are found. The IBM studies revealed that (a) women's values differ less among societies than men's values; (b) men's values from one country to another contain a dimension from very assertive and competitive and maximally different from women's values on the one side, to modest and caring and similar to women's values on the other.

\footnotetext{
${ }^{6}$ http://www.geert-hofstede.com/
} 
The assertive pole has been called 'masculine' and the modest, caring pole 'feminine'. The women in feminine countries have the same modest, caring values as the men; in the masculine countries they are somewhat assertive and competitive, but not as much as the men, so that these countries show a gap between men's values and women's values.

Uncertainty Avoidance Index (UAI) deals with a society's tolerance for uncertainty and ambiguity; it ultimately refers to man's search for Truth. It indicates to what extent a culture programs its members to feel either uncomfortable or comfortable in unstructured situations. Unstructured situations are novel, unknown, surprising, different from usual. Uncertainty avoiding cultures try to minimize the possibility of such situations by strict laws and rules, safety and security measures, and on the philosophical and religious level by a belief in absolute Truth; 'there can only be one Truth and we have it'. People in uncertainty avoiding countries are also more emotional, and motivated by inner nervous energy. The opposite type, uncertainty accepting cultures, are more tolerant of opinions different from what they are used to; they try to have as few rules as possible, and on the philosophical and religious level they are relativist and allow many currents to flow side by side. People within these cultures are more phlegmatic and contemplative, and not expected by their environment to express emotions.

Consistent with Acemoglu and Zilibotti (1999), we conjecture that fund managers operating in legal conditions of poor quality will be more inclined to accept higher fixed fees and lower performance fees. At a general level, information asymmetries are more pronounced in countries with poor legal conditions, and therefore less developed countries are less likely to employ incentive contracts for managers and entrepreneurs (Acemoglu and Zilibotti, 1999). Specifically in the venture capital context, prior empirical work is consistent with the view that countries with weaker legal conditions (based on the La Porta et al., 1998, indices) face more uncertain exit markets whereby it is more difficult to obtain a capital gain and generate fund returns (Lerner and Schoar, 2005; Cumming et al., 2005). As such, we expect risk adverse fund managers to prefer higher fixed fees in exchange for a lower performance fees in order to garner a more certain income stream in countries with weaker legal conditions. Similarly, we expect cultural attributes in a country to affect fees, as Power Distance, Individualism and Masculinity relate to disparity in fees or lower fixed fees and higher performance fees, while uncertainity avoidance is associated with higher fixed fees and lower performance fees.

H1: Fixed management fee percentages will be in higher in countries with a weaker Legality Index, and in countries with less Power Distance, Individualism and Masculinity, and higher Uncertainty Avoidance. 
H2: Carried interest performance fee percentages will be higher in countries with a higher Legality Index, and in countries with more Power Distance, Individualism and Masculinity, and lower Uncertainty Avoidance.

While fund managers benefit from higher fixed fees and lower performance fees in countries with poor legal conditions, institutional investors nevertheless face a particularly pronounced risk of lower profits among funds in countries with poor laws. Institutional investors can lower the downside costs of low returns with the mechanism of a "clawback". A clawback means institutional investors reduce the compensation paid to fund managers in the event of poor performance. A fund usually distributes cash and other proceeds to the fund manager and other investors upon each liquidating event. The problem of excess distributions may occur when earlier liquidations are profitable, and later ones are not. This will be further exacerbated if the fund manager accelerates the sale of profitable investments and holds off the liquidation of bad investments. The clawback allows the investors to recover excess distributions upon liquidation of the fund. ${ }^{7}$ We therefore expect clawbacks to be more frequently employed in countries with poorer legal conditions. We likewise expect clawbacks to be more common in countries with greater Power Distance as it directly reflects bargaining power amongst fund managers and institutional investors.

H3: Clawbacks of fund manager fees in the event of poor performance are more common in countries with a weaker Legality Index and greater Power Distance.

We further expect legal conditions to influence the mode of distribution of fund profits to institutional investors in terms of cash versus share distributions. Poor legal conditions increase the financial risk of share positions in entrepreneurial firms; therefore, all else being equal, the greater the uncertainty created by a lower quality legal environment, the greater the probability of a cash-only distribution policy in the setup of a private fund.

H4: The weaker the legal environment, the greater the probability of covenants mandating cash-only distributions from fund managers to institutional investors.

7 See http://vcexperts.com/vce/library/encyclopedia/glossary_view.asp?glossary_id=188 for a formal definition of clawbacks: "A clawback obligation represents the general partner's promise that, over the life of the fund, the managers will not receive a greater share of the fund's distributions than they bargained for. Generally, this means that the general partner may not keep distributions representing more than a specified percentage (e.g., 20\%) of the fund's cumulative profits, if any. When triggered, the clawback will require that the general partner return to the fund's limited partners an amount equal to what is determined to be "excess" distributions." 
Finally, in an international context private investment funds can be set up offshore, and doing so typically has significant tax advantages. In the US, share distributions are common as the institutional investor can decide when it is the best time to realize capital gains (There are other reasons for share distributions, see e.g., Gompers and Lerner, 1999b, 1997). Since offshore funds are by their very nature tax lowering entities, the timing of realization of capital gains is a less pronounced concern among institutional investors of offshore funds, and therefore the need for share distributions is less pronounced for offshore funds. Furthermore, aside from concerns relating to taxation, offshore funds commonly comprise of various types of institutional investors, such as pension funds, insurance companies, banks, and endowments from a diverse set of countries. Institutional investors from a diverse set of countries typically face non-harmonized legal impediments to acquiring and selling shares in entrepreneurial firms transferred to them from the fund manager. Overall, therefore, offshore funds are expected to mandate cash-only distributions.

H5: Offshore funds are more likely to mandate cash-only distributions from fund managers to institutional investors.

\subsection{Control Variables for Analysing Managerial Compensation across Countries}

Fund manager compensation quite plausibly is influenced by a variety of factors pertaining to economic conditions, institutional investor and fund manager characteristics, including education and experience as well as fund factors such as stage and industry focus, among other factors. We briefly discuss each of these factors in this subsection.

First, in regards to economic conditions, where the demand for fund managers exceeds supply, fund managers are more likely to be compensated better. For instance, in the boom periods a phenomenon of "money chasing deals" (Gompers and Lerner, 2000) typically results, whereby fund managers are short in supply relative to the institutional investors wanting to contribute to the asset class (Kanniainen and Keuschnigg, 2004). As such, fund managers are more likely to have higher fixed fees and carried interest percentages, and less likely to face clawbacks, in times of boom economic conditions (i.e., in countries with stronger economic environments and at times of better stock market performance). 
Second, apart from overall legal quality conditions, specific legal environments pertaining to legal origin might influence fee structures (La Porta et al., 1997, 1998). Cultural differences across regions may also be closely to legal origin variables.

Third, partnership profits from limited partnership funds (carried interest) may be taxed at the capital gains tax rate or deemed as business income and taxed at the income tax rate (unlike venture capital firms set up as corporations) (Fleishcher, 2005). As such, we control for the difference between income tax and capital gains tax rates for limited partnership funds.

Fourth, fund managers that have more education are more likely to receive higher fixed and performance fees, and less likely to face clawbacks. Fund managers with more relevant work experience are more likely to have lower fixed fees but higher carried interest percentages (consistent with the signalling model as discussed in Gompers and Lerner, 1999).

Fifth, fund characteristics such as fund size, stage focus and industry focus can affect fees (Gompers and Lerner, 1999a). Larger funds are more likely to have smaller fixed fees simply because the fixed compensation would be excessive. Funds focused on investing in earlier stages of development and in more high tech industries are more likely to have higher performance fees to incentivise the fund managers and align their interests with that of the institutional investors (since agency problems and information asymmetries are more pronounced among funds focused in early stage and high-tech investments).

Sixth, the type of institutional investor (bank, government, pension fund, etc.) and their respective risk tolerance levels could influence the pay structure of the fund managers in terms of fixed versus managerial fees (for reasons analogous to research in Mayer et al., 2004, and Lerner et al., 2005). As well, the identity of the institutional investors could of course affect the probability of use of clawbacks and the mode of distributions in terms of cash versus shares.

In the empirical analyses of the hypotheses outlined in subsection 2.1, these and other control variables identified in this subsection are used. The data and summary statistics are described in the next section. Thereafter in section 4 multivariate empirical tests are provided. A discussion of limitations, alternative explanation, future research and concluding remarks follows after section 4 . 


\section{Data}

\subsection{Methods and survey instrument}

The data used in this study come mainly from a survey conducted over the period December 2009 and March 2010. The aim of our study is therefore to present a new set of international data corresponding to other countries in the world. The data on fund structure, their size and their investments are mostly available on the financial databases. Otherwise, details of the fees structure of general partners, the terms of recoveries and the profit distribution policy used by the fund (cash against shares) are not publicly revealed by all funds in some countries. On the other hand, most of the agreements used to govern the relationship between managers and investors in the fund are generally written in different languages, so it was necessary to obtain the data by use of surveys and interviews that allow collecting pertinent information. Funds publications on their websites were however used to verify and enhance data obtained by survey and interviews.

We integrate in our sample all investment funds without distinction between private equity funds or venture capital funds. The data collected can be classified into six different groups, which are summarized in Table 1:

- The data related to the compensation of the management partners: \% of management fees, $\%$ of carried interest performance fees, the application of the clawbacks clause, the distribution of cash to institutional investors instead of shares.

- The legal conditions of the country measured by the legality index (La Porta et al. 1997, 1998). The legality index is derived from a principal components analysis of the covariance matrix from the five observed legality variables (Berkowitz, Pistor, and Richard 2000).

- The country's economic conditions: the GNP per capita, the MSCI Index, the Industry market / book ratio calculated according to the sectors targeted by investment funds.

- The characteristics of institutional investors: the proportion of banks institutional investors, government investors...

- The characteristics of the fund: funds size, funds organization (Partnership, Liability Company ...), companies target by funds...

- Characteristics associated to the fund managers specially their training level (the proportion of MBA, CFA or PhD trained fund managers) and relevant experience. 
[Insert Table 1 About Here]

\subsection{Potential sample selection bias}

To summarize, the different sources used in collecting data from the study are as follows:

- The database Thomson One Banker allowed us to collect specific information about funds as its size, creation date and the target firms of the funds...

- The Datastream database allowed us to collect economic information about each country of the sample: the GNP, the MSCI, the Industry Market to Book ratio.

- A questionnaire was sent to officers, general partners and members of management funds. Some respondents preferred a telephone interview. The questionnaire allowed gathering non-published information about general partners (such as their training level, their professional experience, their compensation)

Those potential interviewees were identified from various sources such as:

(1) The Kompass database for the case of French fund managers

(2) The database Thomson One banker to collect the email addresses of fund management teams internationally.

(3) The websites of investment funds.

The survey was sent to approximately 2,500 investment funds in the world by using software for online survey (WysuForms). It has mainly sought the partnership of managers of such funds in the survey with the promise that their results will be communicated to the end of the study. We have verified that a single response is validated for each investment fund. Furthermore, there is a limit in the method of collecting survey data in particular selection bias in the sample. Knowing that this bias is possible, we believe that, after detailed analysis of responses obtained confirm we prove that this bias is avoided in this type of study.

One limitation to obtaining data through a survey is the possibility of sample selection bias. While we acknowledge that this is a possibility, we believe from a detailed analysis of the responses received and the data obtained from the responses that this concern does not arise in this exercise. First, survey data were gathered for a final sample of 123 funds in 23 countries. We are aware that the seminal work carried out by Gompers and Lerner (1996) utilized a sample of 140 contracts used to establish funds, obtained from institutional investors (two fund of funds and one endowment). Litvak (2004b) has data 
from 38 funds in the US, and Metrick and Yasuda (2006) have data from 203 funds in the US. We believe however that by obtaining data from funds situated both in and outside the US, and by having access to data regarding contracts entered into by 123 different fund managers in 23 countries, response bias is mitigated as much as possible. Similarly, Lerner, and Schoar's (2005) study of the relation between legality and venture capital contracts with entrepreneurs is based on data from 28 fund managers. Limitations in our sample size from each country from which we derived data, as well as the limited information about venture capital and private equity funds around the world, however, makes reliable statistical comparisons of our sample relative to the population of funds intractable. Our sample of respondent funds includes twenty-one funds from France, fourteen funds from the US, twelve funds from the UK, eleven funds from the Netherlands and, eight funds from Malaysia, six funds from Germany, five funds each from Australia, Finland and South Africa, four funds each from Brazil and the Netherlands Antilles, three funds each from the Philippines Belgium, Canada, India, Italy,Spain and Switzerland, two funds each from the Cayman Islands and Mexico, and one fund each from the New Zealand Singapore and Luxembourg (see Table 2). The number of respondents, and representation of funds from both developed and emerging private equity markets, makes a response bias even less likely.

Second, a broad array of respondents replied to the survey. For example, the data show the median respondent fund size of US\$70.900.000 and the average being US\$144.667.818 (minimum US\$263.377,5; maximum US\$930.000.000), indicating that respondents were of a variety of fund sizes and of typical size for a sample of non-US countries. The possibility of sample selection bias is further reduced by the presence of both onshore and offshore funds within the final sample, the presence of funds organized not only in both common law and civil law jurisdictions, but also within jurisdictions in legal systems with English, French, Scandinavian and German based legal systems, and also the presence of funds situated in countries where English is not the primary language. Finally, a sufficient number of variables regarding both fund and fund manager organization and the relevant features of the fund asset size, fund vintage, investor composition, investment strategy, industry composition of fund investments and governance structures, more specifically the specific covenants provided in the terms within the agreements that govern the relationship between fund investors and fund manager, were collected to minimize the risk of response bias. We also sought information on the method of calculating management fees, the treatment of other fees such as consulting and monitoring fees, and profit sharing and distribution terms. We 
unfortunatelyrealize that we cannot absolutely rule out the possibility of a response bias as the data we have collected here is unique.

\subsection{Summary statistics}

The summary statistics are presented in Table 3. In the data the average performance fee is $18.01 \%$, and the median performance fee is $20 \%$. The average fixed fee is $2.32 \%$, and the median fixed fee is $2.5 \%$. Thirty four of the 123 funds imposed clawbacks against fund managers in the event of poor performance; the degree of these clawbacks was most often $20 \%$ of the fund manager fees. Eighty seven of the 123 funds mandated cash-only distributions.

The level of the legality index for each country is indicated in Table 2, and for all countries together in Table 3. The legality index is a weighted average of the legal index variables introduced by La Porta et al. (1997, 1998), as defined by Berkowitz, Pistor, and Richard (2003). Each of the components of the legality index is highly pertinent to venture finance, and comprise the efficiency of the judicial system, the rule of law, corruption, risk of expropriation, risk of contract repudiation, and shareholder rights. It is calculated as follows:

Legality Index $=0.381 *($ Efficiency of the Judiciary $)+0.5778^{*}($ Rule of Law $)+0.5031 *$ (Corruption) $+0.3468 *$ (Risk of Expropriation $)+0.3842 *$ (Risk of Contract Repudiation)

The legality index is an appropriate focus of our analysis, in view of the fact that the components of the legality index are very highly correlated, and to focus on a subset of indices within the component of legality to avoid the collinearity problem might tend to have the appearance of data mining. Moreover, as we have a relatively small number of observations, a focus on a weighted average legal index suitably mitigates the possibility of incorrect statistical inferences with outlier observations and the inclusion or exclusion of certain countries in the data. A higher legality index indicates better substantive legal content pertaining to investing, the quality and likelihood of enforcement. Higher numbers indicate 'better' legal systems across each of the factors. Consistent with Hypothesis 1 and Hypothesis 2, Table 4 shows a strong positive correlation (0.51) between the legality index

and performance fees and a strong negative correlation (-0.62) between the legality index and fixed fees.

[Insert Tables 2-4 About Here] 
Eighteen per cent of the funds in the data are outbound offshore funds, and $8 \%$ are inbound offshore funds. As indicated in Table 1, an outbound offshore fund is one that obtains its capital from investors from a certain jurisdiction but fund investments are made primarily in assets other than in the jurisdiction of the fund and the fund investors. With reference to US jurisdictional boundaries, a fund will be considered to be an outbound offshore fund if it obtains capital from US investors, but it invests outside the US. An inbound offshore fund is one that obtains its capital from investors from various jurisdictions but fund investments are made primarily in assets in a certain jurisdiction. With reference to US jurisdictional boundaries, an inbound offshore fund will be a fund located offshore that invests primarily in assets within the US yet obtains its capital from non-US investors.

As these distinctions appear to be important in practice for private investment fund management in an international setting, we control for these variables in our empirical analyses.

A majority of funds are managed by MBA graduates, and a typical fund manager has relevant work experience of about 15.5 years. Science and law graduates exist among some of the funds in the data, and some fund managers had partial training (i.e. some nondegree courses) in law and/or sciences (and this partial training is reflected in our data by recording the proportionate number of years of training). We control for the specific training of the fund managers in our empirical tests.

Seventy-two of 123 funds were set up as limited partnerships, and the remainder were set up as limited liability companies or trusts (see e.g. Cumming and Walz 2004; Cumming, Fleming, and Suchard 2005 and accompanying text on limited partnerships versus other types of fund structures). Thirty one per cent had a pure venture capital (earlystage) focus, and most had a significant exposure to high-tech industries (as reflected by the industry market/book ratio of the investee firms in which the fund had invested). The range across each of the different funds and countries for these and the other variables is detailed in Table 2. 


\section{Econometric Tests}

\subsection{Econometric Methods}

We analyse four different dependent variables in this section: fixed fees (Table 5), Carried interest performance fees (Table 6), clawbacks (Table 7) and cash-only distributions (Table 8). The various right-hand-side explanatory variables were identified in section 3 and defined in Table 1. For each dependent variable we provide 7 alternative sets of regressions to show robustness (for a total of 28 different models, consecutively numbered across Tables $5-8$ ). Tables 5 and 6 make use of standard OLS regression methods corrected for heteroskedasticity with White's estimator (1980). The dependent variable in Tables 5 and 6 are bounded below by zero and above by one; we considered different methods of estimating fractions (Bierens, 2003), but did not find any material differences to the conclusions drawn. Alternative specifications are available upon request. The dependent variables in Tables 7 and 8 are binary variables; as such, we make use of simple logit regressions and again correct for heterockedasticity. Marginal effects for the logit models were computed using Data Analysis and Statistical Software (Stata). The results are also robust to inclusion / exclusion of most of the countries in the data and potential outliers. ${ }^{8}$

We use logs of the right-hand-side variables (except the dummy variables) to reduce the weight of outlier observations and account for diminishing effects. Again, the results are quite robust and alternative specifications are available upon request. In section 5 we describe various other elements of the data, including alternative definitions of variables and variables not employed for reasons of conciseness.

[Insert Tables 5-8 About Here]

\subsection{Regression Results}

The regression results in Tables 5 and 6 indicate that legal conditions by far have the most statistically and economically significant effect on fixed fees and performance compensation. Table 5 indicates fixed fees are significantly lower in countries with stronger legal conditions, and this result is robust to any of the different specifications in

\footnotetext{
${ }^{8}$ One exception to the robustness of results to exclusion of countries is that where the number of observations is significantly reduced by excluding countries, some of the results reported are not robust. Excluding countries with just one fund did not affect the primary results reported.
} 
Models 1-5, among others not presented. This strongly supports H1 outlined above in subsection 2.1. Further, Table 5 indicates legality is the most economically and statistically significant variable in explaining performance fees, strongly in support of $\mathrm{H} 2$. In regards to the economic significance, based on the legal numbers indicated in Table 2, the data indicate that a move from the Brazil to the Switzerland (one of the most extreme improvements in legal conditions in our data) gives rise to a reduction in fixed fees by approximately $1.5 \%$, and an increase in performance fees by approximately $10 \%$. A more modest improvement in legal conditions from the Brazil to South Germany, for example, gives rise to a reduction in fixed fees by approximately $1 \%$ and an increase in performance fees by $8.42 \%$.

These results are robust to the inclusion and/or exclusion of controls for a variety of factors including market conditions, institutional investor and fund manager characteristics, including education and experience as well as fund factors such as stage and industry focus, among other control variables available shown explicitly in the tables (among other considered in the new detailed international dataset, but excluded for reasons of conciseness).

Some of the control variables are significant in Tables 5 and 6 in ways that are expected (as described in subsection 2.2). Larger funds have lower fixed fees (Table 5). Ph.D.'s are more likely to have higher performance fees (Table 6, but this effect is significant only in Model 11). The presence of government investors gives rise to larger fixed fees, and funds focused in high-tech industries (with higher market/book ratios) are more likely to have smaller fixed fees. Managers with extensive work experience are more likely to have higher carried interest (this effect is statistically significant but not very robust on model 10,11 and 13). The other variables, however, are generally insignificant and/or not robust. For example, differences between income and capital gains tax rates do not affect fixed fees versus management fees. Overall, therefore, the most robust variable is legality for explaining international differences in fixed and performance fees.

The model 6 and 7 show that the corruption, a component of the legality index has a negative and significant effect on fixed fees. Countries with high corruption index have low management fees. However, almost all the components of the Legality index have a significant effect on the level of carried interest. The efficiency of Judiciary System induces higher carried interest but the risk of expropriation and corruption reduce the preference of fund managers to receive variable compensation depending on funds 'performance. 
Introducing the cultural dimensions of Hofstede in model 7, shows that Power Distance Index and Individualism have a negative and significant effect on the level of management fees. Anxiety about the unknown, measured by Uncertainty Avoidance Index, induces general partners to require higher management fees (significant result in model 7 of table 5 ).

As in Tables 5 and 6, Table 7 indicates that the legal environment is the most statistically and economically significant determinant of clawbacks among private investment funds across countries, strongly supporting $\mathrm{H} 3$ (subsection 2.1). In terms of the economic significance, a reduction in the quality of legal conditions increases the probability of clawbacks by approximately $33 \%$ for a move from Brazil than Germany, and approximately 50\% for a move from Brazil than Switzerland.

It is important to stress the asymmetric relation between legality and fund manager compensation. Fund managers have higher fixed fees and lower incentive fees in countries with weak legal conditions (Tables 5 and 6). But in regards to penalty clauses, fund managers in countries with weak legal conditions are more likely to face the downside risk of a clawback on their fees (Table 7). The intuition underlying this asymmetric result is possible explained by the fact that risk adverse fund managers trade off a higher fixed fee for a lower performance fee when legal conditions are weak, while risk adverse institutional investors are more likely to require clawbacks to protect against downside risk in countries with poor laws.

The only other significant and robust variable in Table 7 for clawbacks is the MSCI index (model 20). In better market conditions across time, fund managers are less likely to face clawbacks. This is consistent with results in previous work (See e.g. Gompers and Lerner, 1999a,b, 2000 for empirical work; Kanniainen and Keuschnigg, 2004) for theoretical work) which shows demand and supply conditions affect fees. When there is money chasing deals (excess capital flowing from institutional investors to private investment funds for the given inelastic supply of private investment fund managers), fund managers receive more favourable deal terms from their institutional investors.

In regards to the economic significance of legality in Tables 5 and 6 , note that when GNP per capita is included alongside the legality index, the statistical significance of legality is not affected but the economic significance is affected. The reason for this change is the high correlation between legality and GNP per capita (see Table 4). Given 
the bias introduced by simultaneously including both legality and GNP per capita, we feel much more confident with the economic significance associated with only including the legality index without the GNP per capita variable. Note as well in Table 7 that the simultaneous inclusion of GNP per capita and legality gives rise to a statistically insignificant relation between legality and the probability of use of clawbacks. Again, this is due to the high correlation between legality and GNP per capita (Table 4).

Model 21 of table 7, shows that the Power Distance Index is the only cultural dimension that significantly affect clawbacks. When the acceptance of inequality of power is emphasized in a given country, the probability of use of clawbacks will be higher.

Table 8 analyses the relation between legality and payment terms to a fund's institutional investors in terms of cash versus share distributions from realized investments in entrepreneurial firms. The Logit regression indicates a robust relation between legality and cash distributions in Model 23. The other models 22, 25 and 26 are less significant but showed the same relation (These results confirm the hypothesis $\mathrm{H} 4$ in subsection 2.1): cash only distributions are more likely in countries with weak legal conditions.

Much more significantly in Table 8 , however, is the result that institutional investors mandate cash-only distributions for off-shore funds. The estimates coefficients for legality in Models 22-27 provides very strong support for H5 outlined in subsection 2.1. In regards to the economic significance, institutional investors are approximately $77.78 \%$ more likely to require cash-only distributions when the fund is established as an offshore fund. As conjectured and explained in subsection 2.1, this finding is consistent with the view that share distributions for tax reasons are less meaningful since offshore funds are already tax pass through entities. Furthermore, institutional investors in an offshore fund are commonly from a diverse set of countries, and they typically face non-harmonized legal impediments to selling shares in entrepreneurial firms transferred to them from the fund manager. Hence, it is much more efficient for liquidity reasons to have cash-only distributions among offshore fund structures.

The other significant and robust variable in Table 8 for Cash versus Share Distributions is the Legality index. In terms of the economic significance, a reduction in the quality of legal conditions increases the probability that institutional investors mandate cash-only distributions. On the other hand, better market conditions illustrated by a higher GNP per Capita in model 22 or a higher MSCI index in model 24, 25 and 27 have a positive effect on Cash Distributions. Institutional investors will rather prefer to receive cash and invest it in the market since there is a favorable economic situation. 


\section{Conclusion}

There has been a growing concern over fee structures since the financial crisis. International law firms such as S.J. Berwin have been highlighting the role of corruption and law in setting fees and governance in the private equity industry: "Private equity funds that use agents, advisers or consultants to conduct business on their behalf without proper due diligence, training or monitoring, and business partners that lack transparency in their books and records should also place the fund on alert, as should unusual or unclear sales timings, transactions or payment routes, and any non-standard contractual terms."

Based on a sample of 123 venture capital and private equity funds around the world, we find that in countries with better legal conditions, fixed fees are lower, carried interest fees are higher, clawbacks are less likely, and share distributions are more likely. These findings support the idea that legal conditions help to align the interests of managers and shareholders. We extend our empirical analyses to ascertain what specific legal conditions matter across countries. We find that corruption levels play a pronounced role in shaping fund manager fee contracts across countries. For example, corruption is the only significant legal determinant of setting fixed fees such that fixed fees are lower in less corrupt countries. We also show that cultural forces such as Hofstede`s measures of power distance and uncertainty avoidance likewise play a role in influencing fees. Overall, it is noteworthy that laws and culture are much more significant in determining fees than fund manager characteristics and/or market conditions.

Consistent with the theoretical work Acemoglu and Zilibotti (1999), risk adverse private fund managers substitute fixed compensation for incentive compensation as legal conditions worsen. The data in fact indicated that legal and cultural conditions by far have the most statistically and economically significant effect on compensation, even in comparison to the role of the managers education and experience, as well as a variety of other fund characteristics including fund size and industry and stage focus.

While risk adverse fund managers trade-off performance fees for fixed fees in countries with poor laws, risk adverse institutional investors are also more likely to require clawbacks of fund manager fees in the event of poor fund performance. In other words, there is an asymmetry in fund manager compensation in relation to legal conditions: fund managers have higher fixed fees and lower incentive fees in countries with weak legal 
conditions, but fund managers in countries with weak legal conditions are also more likely to face the downside risk of a clawback on their fees.

That legal conditions affect the payment conditions of fund managers and institutional investors across countries has a number of implications for future research. Legal and cultural conditions influence fund manager compensation, which in turn could have implications for fund investment selection, returns and the development of private equity markets across countries. The comparative importance for law versus culture in compensation contracts versus the role of law directly in other aspects of fund management could be a fruitful avenue for future research.

\section{References}

Acemoglu, D., and F. Zilibotti, 1999. Information accumulation in development, Journal of Economic Growth 4, 5-38.

Allen, F., and Song, W.L., 2003. Venture capital and corporate governance. in Corporate Governance and Capital Flows in a Global Economy, edited by Cornelius, P.K and Kogut, B., Oxford University Press, New York, 133-156.

Bascha, A. and Walz., U., 2001, Financing practices in the German venture capital industry: an empirical assessment, (Working Paper, Center for Financial Studies, Frankfurt)

Bebchuk, L.A and Fried, J.M., 2004, Pay Without Performance: The Unfulfilled Promise of Executive Compensation. Harvard University Press.

Bierens, H.J., 2004. Modeling fractions, Research note 2003 posted online at: http://econ.la.psu.edu/ hbierens/EasyRegTours/FRACTIONS.PDF (accessed 1 June 2004)

Black, B.S. and Gilson, R.J., 1998, Venture capital and the structure of capital markets: banks versus stock markets., Journal of Financial Economics, 47 , 243-277.

Berkowitz, D., Pistor, K and Richard, J.F., 2003, Economic development, legality, and the transplant effect., European Economic Review, 47, 165-195.

Casamatta, C., 2003, Financing and advising: optimal financial contracts with venture capitalists, Journal of Finance 58, 2059 - 2086.

Chevalier, J. and Ellison, G., 1997, Risk taking by mutual funds as a response to incentives, Journal of Political Economy 114, 389-432.

Chevalier, J. and Ellison, G., 1999, Career concerns of mutual fund managers, Quarterly Journal of Economics 105, 1167-1200.

Chevalier, J. and Ellison, G., 1999, Are some mutual fund managers better than others? Cross-sectional patterns in behaviour and performance, Journal of Finance 54, 875-899. 
Cressy, R.C, 2002. Introduction: Funding Gaps. The Economic Journal 112, F1-F16.

Cressy, R.C., and Toivanen, O., 2001, Is there adverse selection in the credit market? Venture Capital: An International Journal of Entrepreneurial Finance 3, 215-238.

Cressy, R., Malipiero, A., and Munari, F., 2006, Playing to their strengths? Evidence that specialization in the private equity industry confers competitive advantage, Journal of Corporate Finance 13, 647-669.

Cumming, D.J., Fleming, G. and Schwienbacher, A., 2006, Legality and venture capital exits, Journal of Corporate Finance 12, 214-245.

Cumming, D.J. Fleming, G and Suchard, J., 2005, Venture capitalist value-added activities, fundraising and drawdowns, Journal of Banking and Finance 29, 295-331.

Cumming, D.J. and Johan, S.A., 2006, Is it the law or the lawyers? Investment fund covenants across countries, European Financial Management,

Cumming, D.J., and Johan, S.A., 2009. Legality and Fund Manager Compensation, Venture Capital: An International Journal of Entrepreneurial Finance

Cumming, D.J. and Walz, U., 2010, Private equity returns and disclosure around the world, Journal of International Business Studies

Dai, N., 2007. Does investor identity matter? An empirical examination of investments by venture capital funds and hedge funds in PIPEs, Journal of Corporate Finance 13, 538-563.

Elton, Edwin J., Gruber, Martin J. and Blake, Christopher R., 2003, Incentive Fees and Mutual Funds, Journal of Finance, 58, 779-804.

Fisman, R and DiTella, R, 2002, Are Politicians Paid Like Bureaucrats?, Journal of Law and Economics, XXVII, 477-513

Fleishcher, V., 2005, The missing preferred return, (Working Paper, UCLA Law School).

Gilson, R.J. and Schizer, D., 2003, Venture capital structure: a tax explanation for convertible preferred stock, Harvard Law Review, 116, 875-916.

Gompers, P.A. and Lerner, J., 1996, The use of covenants: an empirical analysis of venture capital partnership agreements, Journal of Law and Economics 39, 463-498.

Gompers, P.A., and Lerner, J., 1997, Venture capital distributions: short run and long run reactions, Journal of Finance 53, 2161-2183.

Gompers, P.A., and Lerner, J., 1999, An Analysis of Compensation in the US Venture Capital Partnership, Journal of Financial Economics 55, 3

Gompers, P.A., and Lerner, J., 1999, The Venture Capital Cycle. Cambridge: MIT Press.

Hazarika, S., R. Nahjata, and K. Tandon, 2009. Success in Global Venture Capital Investing: Do Institutional and Cultural Differences Matter? Working Paper, Baruch College. 
Hege, U., Palomino, F. and Schwienbacher, A., 2009, Determinants of venture capital performance: Europe and the United States, Revue Finance

Hsu, D., 2004, What do entrepreneurs pay for venture capital affiliation? Journal of Finance, $59,1805-1844$.

Jeng, L.A., and Wells, P.C., 2000, The determinants of venture capital fundraising: evidence across countries, Journal of Corporate Finance 6, 241-89.

Ivanov, V., C.N.V. Krishnan, R. Masulis and A. Singh, 2009. Venture Capital Reputation, Post-IPO Performance and Corporate Governance, Journal of Financial and Quantitative Analysis, forthcoming.

Kanniainen, V, and Keuschnigg, C., 2003, The optimal portfolio of start-up firms in venture capital finance, Journal of Corporate Finance 9, 521-534.

Kanniainen, V., and Keuschnigg, C., 2004, Start-up investment with scarce venture capital support, Journal of Banking and Finance 28, 1935-1959.

Keuschnigg, C., 2003, Public policy and venture capital backed innovation, (Working Paper No. 2003-09, University of St. Gallen).

Keuschnigg, C., 2004, Venture capital backed growth, Journal of Economic Growth 9, 239261.

Keuschnigg, C., 2004, Taxation of a venture capitalist with a portfolio of firms, Oxford Economic Papers 56, 285-306.

Keuschnigg, C. and Nielsen, S.B., 2001, Public policy for venture capital, International Tax and Public Finance 8, 557-572.

Keuschnigg, C. and Nielsen, S.B., 2003a, Tax policy, venture capital and entrepreneurship, Journal of Public Economics 87, 175-203.

Keuschnigg, C. and Nielsen, S.B., 2003b, Taxes and venture capital support, Review of Finance 7, 515-539.

Keuschnigg, C. and Nielsen, S.B., 2004a, Progressive taxation, moral hazard, and entrepreneurship, Journal of Public Economic Theory 6, 471-490.

Keuschnigg, C. and Nielsen, S.B., 2004b, Start-ups, venture capitalists, and the capital gains tax, Journal of Public Economics 88, 1011-1042.

La Porta, R., Lopez-De-Silanes, F., Shleifer, A and Vishny, R., 1997, Legal determinants of external finance, Journal of Finance 52, 1131-1150.

La Porta, R., Lopez-De-Silanes, F., Shleifer, A and Vishny, R., 1998, Law and finance, Journal of Political Economy 106, 1113-1155.

Lerner, J. and Schoar, A., 2005, Does legal enforcement affect financial transactions? The contractual channel in private equity, The Quarterly Journal Economics 120, Issue 1, 223246. 
Litvak, K., 2004, Governance through exit: default penalties and walkaway options in venture capital partnership agreements, Working Paper, University of Texas Law School.

Litvak, K., 2004, Venture capital limited partnership agreements: understanding compensation arrangements, Working Paper, University of Texas Law School.

Lockett, A., Wright, M., Pruthi, S. and Sapienza, H., 2002, Venture capital investors, valuation and information: a comparative study of US, Hong Kong, India and Singapore, Venture Capital: An International Journal of Entrepreneurial Finance 4, 2002, 237-252.

Manigart, S., DeWaele, K., Wright, M., Robbie, K., Desbrieres, P., Sapienza, H. and Beekman, A., 2002, The determinants of the required returns in venture capital investments: a five-country study, Journal of Business Venturing 17, 291-312.

Mayer, C., Schoors, K., and Yafeh, Y., 2005, Sources of funds and investment activities of venture capital funds: evidence from Germany, Israel, Japan and the UK. Journal of Corporate Finance 11, 586-608

McCahery, J. A. and Vermeulen, E.P.M, 2004, Business organization law and venture capital in Venture Capital Contracting and the Valuation of High Technology Firms edited by McCahery, J.A and Renneboog, L, Oxford University Press, $162-187$.

Metrick, A., and A. Yasuda, 2009. Economics of private equity funds, Review of Financial Studies, forthcoming

Nikoskelainen, E., and M. Wright, 2007. The impact of corporate governance mechanisms on value increase in leveraged buyouts, Journal of Corporate Finance 13, 511-537.

Poterba, J., 1989, Capital gains tax policy towards entrepreneurship, National Tax Journal $42,375-389$.

Poterba, J., 1989, Venture capital and capital gains taxation in Tax Policy and the Economy 3 (ed) Summers, Lawrence H, Cambridge: MIT Press 47-67.

Renneboog, L., T. Simons and M. Wright, 2007. Why do public firms go private in the UK? The impact of private equity investors, incentive realignment and undervaluation, Journal of Corporate Finance 13, 591-628

Sahlman, W.A., 1990, The structure and governance of venture capital organizations, Journal of Financial Economics 27, 473-521.

Schmidt, K.M., 2003, Convertible securities and venture capital finance, Journal of Finance $58,2003,1139-1166$.

Schwienbacher, A., 2002, An empirical analysis of venture capital exits in Europe and the United States, (Working paper, University of Amsterdam, 2002).

White, H., 1980, A heteroskedasticity-consistent covariance matrix estimator and a direct test for heteroskedasticity, Econometrica 48, 817-838. 


\section{Table 1. Definition of Variables}

This table defines the variables considered in this paper. Summary statistics are presented in Tables 2 and 3.

\begin{tabular}{|c|c|}
\hline Variable & Description \\
\hline \multicolumn{2}{|l|}{ Compensation Variables } \\
\hline Fixed Management Fee \% & The fund managers' fixed fee as a percentage of the funds raised from the institutional investors. \\
\hline $\begin{array}{c}\text { Carried Interest } \\
\text { Performance Fee \% }\end{array}$ & The fund managers' carried interest performance fees as a percentage of the profits earned by the fund. \\
\hline Clawbacks & $\begin{array}{l}\text { A dummy variable equal to one if the fund allows for clawbacks against the fund managers but not any } \\
\text { of the fund investors. A clawback enables the fund investors to lower the fee received by the fund } \\
\text { manager in the event of poor performance of the fund. }\end{array}$ \\
\hline Cash Distributions & $\begin{array}{l}\text { A dummy variable equal to one if the fund managers are required to distribute cash to the institutional } \\
\text { investors instead of shares (for realized capital gains from investments in entrepreneurial firms). }\end{array}$ \\
\hline
\end{tabular}

Legal and Market Conditions

\begin{tabular}{|c|c|}
\hline Country Legality Index & $\begin{array}{l}\text { Weighted average of following factors (based on Berkowitz et al., 2003): efficiency of judicial system, } \\
\text { rule of law, corruption, risk of expropriation, risk of contract repudiation, shareholder rights (as per La } \\
\text { Porta et al., 1997, 1998). Where the weighted average is not available, especially for less developed } \\
\text { countries, an approximate index is derived by multiplying the country's GNP per population with a } \\
\text { constant variable obtained by carrying out a regression of the legality indices available. Higher } \\
\text { numbers indicate 'better' legal systems. The log of this variable is used in the empirics to account for a } \\
\text { diminishing effect with larger numbers. }\end{array}$ \\
\hline Legal Origin & $\begin{array}{l}\text { Dummy variables equal to } 1 \text { for a fund organized in countries of different legal origin, including } \\
\text { English, French, German and Scandinavian. }\end{array}$ \\
\hline $\begin{array}{l}\text { Hofstede Cultural } \\
\text { Dimensions }\end{array}$ & $\begin{array}{l}\text { Hofstede's study demonstrated that there are national and regional cultural groupings that affect the } \\
\text { behavior of societies and organizations, and that these are persistent across time. Hofstede has found } \\
\text { five dimensions of culture in his study of national work related values. The dimensions are: Small vs. } \\
\text { large power distance, Individualism vs. Collectivism, Masculinity vs. Femininity, Weak vs. strong } \\
\text { uncertainty avoidance and Long vs. short term orientation. }\end{array}$ \\
\hline GNP per Capita & The GNP per Capita of the country in which the fund is formed. The log of this variable is used. \\
\hline MSCI Index & $\begin{array}{l}\text { The country-specific MSCI Index taken for the year prior to that when fund raising commenced } \text {. The } \\
\text { year prior to fund raising is deemed to be most relevant as decisions to invest in private equity by } \\
\text { institutional investors will be based on available economic indicators. The log of (1+MSCI) is used } \\
\text { in the empirics to account for a diminishing effect with larger numbers. }\end{array}$ \\
\hline Vintage Year of Fund & The year fund raising commences \\
\hline Outbound offshore & $\begin{array}{l}\text { A dummy variable equal to } 1 \text { for a fund located offshore that obtains its capital from investors from a } \\
\text { certain jurisdiction but fund investments are made primarily in assets other than in the jurisdiction of } \\
\text { the fund and the fund investors. With reference to United States jurisdictional boundaries, a fund will } \\
\text { be considered to be an outbound offshore fund if it obtains capital from United States investors, but it } \\
\text { invests outside the United States. }\end{array}$ \\
\hline Inbound offshore & $\begin{array}{l}\text { A dummy variable equal to } 1 \text { for a fund located offshore that obtains its capital from investors from } \\
\text { various jurisdictions but fund investments are made primarily in assets in a certain jurisdiction. With }\end{array}$ \\
\hline
\end{tabular}




\begin{tabular}{|c|c|}
\hline & $\begin{array}{l}\text { reference to United States jurisdictional boundaries, an inbound offshore fund will be a fund located } \\
\text { offshore which invests primarily in assets within the United States yet obtains its capital from non- } \\
\text { United States investors. }\end{array}$ \\
\hline Tax Difference & $\begin{array}{l}\text { A variable equal to, for top marginal tax rates, (Income Tax Rate - Capital Gains Tax Rate)*(Limited } \\
\text { Partnership Dummy Variable), for partnerships for which carried interest is taxed at the capital gains } \\
\text { rate, and fixed management fees are taxed at the income tax rate. }\end{array}$ \\
\hline \multicolumn{2}{|l|}{ Fund Manager Characteristics } \\
\hline $\begin{array}{l}\text { Percentage of Legally } \\
\text { Trained Fund Managers }\end{array}$ & $\begin{array}{l}\text { Percentage of principal fund managers with investment making decisions who are legally trained, or } \\
\text { are qualified as lawyers. Where managers have some extent of legal training, that fraction of the } \\
\text { extent of legal training is also reflected in the data. }\end{array}$ \\
\hline $\begin{array}{l}\text { Percentage of MBA/CFA } \\
\text { Trained Fund Managers }\end{array}$ & $\begin{array}{l}\text { Percentage of principal fund managers with investment making decisions who have obtained an MBA } \\
\text { or CFA qualifications. Where managers have some extent of such training, that fraction is also } \\
\text { reflected in the data. }\end{array}$ \\
\hline $\begin{array}{l}\text { Percentage of } \mathrm{PhD} \\
\text { (Science) Trained Fund } \\
\text { Managers }\end{array}$ & $\begin{array}{l}\text { Percentage of principal fund managers with investment making decisions who have obtained a } \mathrm{PhD} \text { in } \\
\text { a science based discipline. Where managers have some extent of formal scientific training, that } \\
\text { fraction of training is also reflected in the data. }\end{array}$ \\
\hline $\begin{array}{l}\text { Percentage of PhD (Non- } \\
\text { Science) Trained Fund } \\
\text { Managers }\end{array}$ & $\begin{array}{l}\text { Percentage of principal fund managers with investment making decisions who have obtained a PhD in } \\
\text { a non-science based discipline. Where managers have some extent of advanced Ph.D. studies, that } \\
\text { fraction of training is also reflected in the data. }\end{array}$ \\
\hline $\begin{array}{l}\text { Average \# Years of } \\
\text { Relevant Work Experience } \\
\text { of Principal Fund } \\
\text { Managers }\end{array}$ & $\begin{array}{l}\text { Average number of years relevant work experience of principal fund managers at the time of fund } \\
\text { raising. The log of this variable is used in the empirics to account for a diminishing effect with larger } \\
\text { numbers. }\end{array}$ \\
\hline \multicolumn{2}{|l|}{ Fund Characteristics } \\
\hline Funds Raised & $\begin{array}{l}\text { The fund size, or amount of funds raised in US Dollar. Where the amount is provided in a local } \\
\text { currency, an exchange rate as at December } 2003 \text { is used for conversion of such amounts into US Dollar } \\
\text { equivalents. The log of this variable is used in the empirics to account for a diminishing effect with } \\
\text { larger numbers. }\end{array}$ \\
\hline Bank Institutional Investors & The proportion of banks as the fund's institutional investors \\
\hline Government Investors & The proportion of government agencies or ministries as institutional investors \\
\hline Limited Partnership Funds & A dummy variable equal to 1 for the fund being organized as a limited partnership. \\
\hline Industry Market / Book & $\begin{array}{c}\text { The industry market/book ratio of the industries for which the fund has invested in. The industry } \\
\text { market/book ratio of } 5 \text { general categories, Biotechnology and Medical, Communications and Internet, } \\
\text { Computers and Electronics, Manufacturing and others, is obtained by averaging the total book value } \\
\text { of specific industries falling within the general categories. The log of this variable is used in the } \\
\text { empirics to account for a diminishing effect with larger numbers. }\end{array}$ \\
\hline Early Stage Investee Focus & $\begin{array}{l}\text { A dummy variable equal to } 1 \text { for funds which indicate a focus on financing provided to firms in their } \\
\text { early / expansion stages of development (not late stages or buyout stages). More specific stages of } \\
\text { focus were not tractable due to international differences in the definition of stage focus, as well as style } \\
\text { drift that is often observed among different stages of development. }\end{array}$ \\
\hline
\end{tabular}


Table 2. Summary of the Data

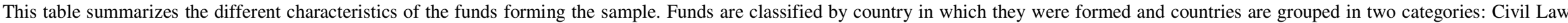
and Common Law. The average values of each variable per country are reported (except for Clawbacks and Cash distribution, where the number of funds is reported).

\begin{tabular}{|c|c|c|c|c|c|c|c|c|c|c|c|c|c|c|}
\hline \multicolumn{15}{|c|}{ Table 2.a Summary of the Data (Civil Law) } \\
\hline & Total & Belgium & Brazil & Finland & France & Germany & Italy & Luxembourg & Mexico & Netherlands & $\begin{array}{l}\text { Netherlands } \\
\text { Antilles }\end{array}$ & Philippines & Spain & Switzerland \\
\hline Number of funds & 69 & 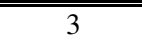 & 4 & 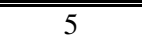 & 21 & "6 & 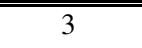 & 1 & 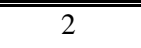 & 11 & "4 & 3 & 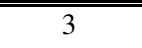 & 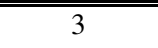 \\
\hline \multicolumn{15}{|l|}{ Compensation } \\
\hline Management fees (\%) & 2.34 & 2.33 & 3.50 & 2.50 & 2.14 & 2.50 & 2.50 & 2.00 & 3.00 & 2.32 & 0.80 & 2.00 & 2.33 & 2 \\
\hline Carried Interest (\%) & 18.82 & 20.00 & 10.75 & 20.00 & 19.33 & 19.17 & 20.00 & 20.00 & 20.00 & 20.09 & 15.00 & 20.00 & 20.00 & 20.33 \\
\hline Clawbacks & 15 & 0 & 2 & 1 & 9 & 1 & 1 & 0.00 & 0.00 & 1 & 0 & 0 & 0 & 0 \\
\hline Cash Distribution & 48 & 1 & 4 & 4 & 17 & 3 & 3 & 1.00 & 1.00 & 4 & 4 & 1 & 3 & 2 \\
\hline \multicolumn{15}{|c|}{ Legal and Market Conditions } \\
\hline Legality Index & 19.26 & 20.82 & 14.09 & 21.49 & 19.67 & 20.44 & 17.23 & 21.91 & 12.82 & 21.67 & 21.67 & 8.51 & 17.13 & 21.91 \\
\hline GNP per Capita & 22668.89 & 21650.00 & 6788.22 & 32134.24 & 24467.97 & 27178.75 & 20324.97 & 35760.00 & 6772.10 & 25058.18 & 20950.00 & 20981.60 & 24938.67 & 37156.23 \\
\hline MSCI Index & 6047.13 & 0.19 & 60109.48 & 657.98 & 1123.03 & 379.17 & 743.86 & 0.01 & 12750.97 & 278.23 & 0.16 & 935.16 & 1042.07 & 592.36 \\
\hline Vintage Year of fund & 2000.70 & 1999.33 & 2002.00 & 2003.80 & 1999.00 & 2001.33 & 2000.33 & 1997.00 & 2003.00 & 1999.73 & 2000.25 & 1999.00 & 2004.67 & 1999.67 \\
\hline Outbound Offshore & 0.19 & 0.00 & 0.00 & 0.20 & 0.00 & 0.17 & 0.00 & 1.00 & 0.00 & 0.09 & 1.00 & 0.00 & 0.00 & 0.00 \\
\hline Inbound Offshore & 0.05 & 0.00 & 0.00 & 0.00 & 0.05 & 0.00 & 0.00 & 0.00 & 0.50 & 0.09 & 0.00 & 0.00 & 0.00 & 0.00 \\
\hline \multicolumn{15}{|c|}{ Fund Manager Characteristics } \\
\hline $\begin{array}{l}\text { Proportion of MBA/CFA } \\
(\%)\end{array}$ & 67.40 & 58.33 & 83.75 & 61.00 & 39.68 & 65.00 & 38.33 & 80.00 & 90.00 & 61.82 & 80.00 & 100.00 & 61.67 & 56.67 \\
\hline Proportion of Ph.D (\%) & 13.38 & 33.33 & 0.00 & 2.20 & 24.35 & 5.83 & 16.67 & 5.00 & 0.50 & 7.36 & 5.00 & 33.33 & 17.00 & 23.33 \\
\hline $\begin{array}{l}\text { Proportion of Legally } \\
\text { trained manager }(\%)\end{array}$ & 7.38 & 8.33 & 13.75 & 5.00 & 13.46 & 2.83 & 21.67 & 5.00 & 1.00 & 10.91 & 0.00 & 0.00 & 4.00 & 10.00 \\
\hline $\begin{array}{l}\text { Years Relevant Work } \\
\text { Experience }\end{array}$ & 15.33 & 11.33 & 15.50 & 13.60 & 14.14 & 15.83 & 15.67 & 10.00 & 25.00 & 12.18 & 14.00 & 25.00 & 14.00 & 13.00 \\
\hline Funds Raised & $1.87 \mathrm{E}+08$ & $1.43 \mathrm{E}+08$ & $2.45 \mathrm{E}+08$ & $9.91 \mathrm{E}+07$ & $2.19 \mathrm{E}+08$ & $1.73 \mathrm{E}+08$ & $2.18 \mathrm{E}+08$ & $3.60 \mathrm{E}+07$ & $4.79 \mathrm{E}+07$ & $3.93 \mathrm{E}+07$ & $3.04 \mathrm{E}+08$ & $5.30 \mathrm{E}+08$ & $2.30 \mathrm{E}+08$ & $1.47 \mathrm{E}+08$ \\
\hline $\begin{array}{l}\text { Bank Institutional } \\
\text { Investors }\end{array}$ & 0.20 & 0.56 & 0.08 & 0.01 & 0.30 & 0.45 & 0.35 & 0.24 & 0.00 & 0.18 & 0.10 & 0.04 & 0.12 & 0.16 \\
\hline Government Investors & 0.06 & 0.06 & 0.10 & 0.11 & 0.03 & 0.07 & 0.02 & 0.00 & 0.00 & 0.21 & 0.10 & 0.02 & 0.03 & 0.03 \\
\hline Pension Investors & 0.11 & 0.05 & 0.50 & 0.21 & 0.19 & 0.02 & 0.09 & 0.00 & 0.00 & 0.11 & 0.10 & 0.00 & 0.10 & 0.03 \\
\hline Endowment Investors & 0.04 & 0.00 & 0.00 & 0.16 & 0.08 & 0.03 & 0.05 & 0.00 & 0.00 & 0.03 & 0.10 & 0.00 & 0.04 & 0.05 \\
\hline limited Partnership Funds & 0.55 & 0.00 & 0.50 & 0.80 & 0.62 & 0.83 & 0.67 & 0.00 & 0.50 & 0.27 & 1.00 & 1.00 & 0.67 & 0.33 \\
\hline Industry Market/Book & 3.84 & 3.89 & 3.19 & 4.01 & 3.44 & 3.52 & 2.93 & 4.75 & 1.88 & 3.39 & 4.82 & 4.21 & 4.73 & 5.18 \\
\hline Early-stage Investee Focus & 0.37 & 0.33 & 0.00 & 0.40 & 0.29 & 0.50 & 1.00 & 0.00 & 0.00 & 0.27 & 0.00 & 1.00 & 0.67 & 0.33 \\
\hline
\end{tabular}




\begin{tabular}{|c|c|c|c|c|c|c|c|c|c|c|c|}
\hline & Total & Australia & Canada & Cayman Islands & India & Malaysia & New Zealand & Singapore & South Africa & U.K & U.S.A \\
\hline Number of funds & 54 & 5 & 3 & 2 & 3 & 8 & $\overline{1}$ & $\overline{1}$ & 5 & 12 & 14 \\
\hline \multicolumn{12}{|l|}{ Compensation } \\
\hline Management fees (\%) & 2.30 & 1.90 & 2.00 & 2.50 & 3.67 & 2.25 & 2.32 & 2.00 & 2.19 & 2.08 & 2.08 \\
\hline Carried Interest (\%) & 17.96 & 20.00 & 20.00 & 12.50 & 18.67 & 19.50 & 20.09 & 20.00 & 11.50 & 19.67 & 17.64 \\
\hline Clawbacks & 18 & 1 & 1 & 0 & 2 & 5 & 1 & 0.00 & 2.00 & 2 & 4 \\
\hline Cash Distribution & 40 & 4 & 2 & 1 & 3 & 3 & 4 & 1.00 & 3.00 & 9 & 10 \\
\hline \multicolumn{12}{|l|}{ Legal and Market Conditions } \\
\hline Legality Index & 18.84 & 20.44 & 21.13 & 20.41 & 12.8 & 16.67 & 21.67 & 19.53 & 14.51 & 20.41 & 20.85 \\
\hline GNP per Capita & 17868.93 & 29222.88 & 22602.23 & 18060.00 & 670.00 & 5176.54 & 25058.18 & 20981.60 & 3331.82 & 25108.51 & 28477.50 \\
\hline MSCI Index & 409.67 & 681.77 & 534.28 & 0.14 & 281.80 & 63.72 & 278.23 & 935.16 & 177.00 & 783.85 & 360.73 \\
\hline Vintage Year of fund & 2001.34 & 2001.60 & 2002.33 & 1999.00 & 2004.67 & 2002.00 & 1999.73 & 1999.00 & 2002.80 & 2002.00 & 2000.29 \\
\hline Outbound Offshore & 0.14 & 0.00 & 0.33 & 0.00 & 0.00 & 0.25 & 0.09 & 0.00 & 0.20 & 0.33 & 0.21 \\
\hline Inbound Offshore & 0.12 & 0.00 & 0.00 & 0.50 & 0.33 & 0.00 & 0.09 & 0.00 & 0.00 & 0.25 & 0.07 \\
\hline \multicolumn{12}{|l|}{ Fund Manager Characteristics } \\
\hline Proportion of MBA/CFA (\%) & 78.38 & 66.67 & 64.00 & 90.00 & 100.00 & 80.00 & 61.82 & 100.00 & 79.40 & 66.08 & 75.79 \\
\hline Proportion of Ph.D (\%) & 9.04 & 10.40 & 3.33 & 2.50 & 2.00 & 7.13 & 7.36 & 33.33 & 1.60 & 14.58 & 8.21 \\
\hline $\begin{array}{l}\text { Proportion of Legally trained } \\
\text { manager }(\%)\end{array}$ & 8.74 & 15.67 & 13.00 & 2.50 & 33.33 & 3.13 & 10.91 & 0.00 & 0.20 & 4.50 & 4.17 \\
\hline $\begin{array}{l}\text { Years Relevant Work } \\
\text { Experience }\end{array}$ & 15.90 & 19.00 & 15.33 & 17.00 & 11.00 & 15.81 & 12.18 & 25.00 & 12.80 & 14.25 & 16.64 \\
\hline Funds Raised & $1.51 \mathrm{E}+08$ & $2.45 \mathrm{E}+08$ & $5.66 \mathrm{E}+07$ & $2.45 \mathrm{E}+08$ & $4.90 \mathrm{E}+07$ & $3.40 \mathrm{E}+07$ & $3.93 \mathrm{E}+07$ & $5.30 \mathrm{E}+08$ & $3.88 \mathrm{E}+07$ & $1.63 \mathrm{E}+08$ & $1.10 \mathrm{E}+08$ \\
\hline Bank Institutional Investors & 0.11 & 0.11 & 0.19 & 0.09 & 0.03 & 0.18 & 0.18 & 0.04 & 0.08 & 0.09 & 0.11 \\
\hline Government Investors & 0.13 & 0.00 & 0.00 & 0.05 & 0.34 & 0.24 & 0.21 & 0.02 & 0.27 & 0.13 & 0.06 \\
\hline Pension Investors & 0.20 & 0.67 & 0.40 & 0.05 & 0.02 & 0.17 & 0.11 & 0.00 & 0.22 & 0.16 & 0.19 \\
\hline Endowment Investors & 0.04 & 0.08 & 0.15 & 0.05 & 0.00 & 0.00 & 0.03 & 0.00 & 0.00 & 0.06 & 0.07 \\
\hline limited Partnership Funds & 0.59 & 0.40 & 0.67 & 1.00 & 0.33 & 0.13 & 0.27 & 1.00 & 0.40 & 0.83 & 0.86 \\
\hline Industry Market/Book & 4.52 & 4.43 & 2.95 & 4.37 & 10.22 & 3.72 & 3.39 & 4.21 & 3.92 & 3.99 & 3.96 \\
\hline Early-stage Investee Focus & 0.38 & 0.20 & 0.67 & 0.00 & 0.67 & 0.13 & 0.27 & 1.00 & 0.20 & 0.33 & 0.29 \\
\hline
\end{tabular}




\begin{tabular}{|c|c|c|c|c|c|}
\hline & Median & Mean & Min & Max & $\begin{array}{c}\text { Number of } \\
\text { observations }\end{array}$ \\
\hline $\begin{array}{l}\text { Legal and Market Conditions } \\
\text { Management fees }(\%)\end{array}$ & 2.5 & 2.320 & 0.8 & 5 & 123 \\
\hline Carried Interest (\%) & 20 & 18.32 & 6 & 21 & 123 \\
\hline Clawbacks & 0 & 0.276 & 0 & 1 & 34 \\
\hline Cash Distribution & 1 & 0.707 & 0 & 1 & 87 \\
\hline legality Index & 20.41 & 19.167 & 8.51 & 21.91 & 123 \\
\hline English Legal Origin & 0 & 0.455 & 0 & 1 & 56 \\
\hline French Legal Origin & 0 & 0.374 & 0 & 1 & 46 \\
\hline German Legal Origin & 0 & 0.073 & 0 & 1 & 9 \\
\hline Scandin Legal Origin & 0 & 0.041 & 0 & 1 & 5 \\
\hline GNP per Capita & $23,168.4$ & $21,400.170$ & 480.9 & $46,543.7$ & 123 \\
\hline MSCI Index & 483.446 & 2673.854 & -0.629713043 & 173293.1 & 123 \\
\hline Year of Fund Formation & 2001 & 2000.919 & 1980 & 2008 & 123 \\
\hline Outbound Offshore & 0 & 0.163 & 0 & 1 & 20 \\
\hline Inbound Offshore & 0 & 0.073 & 0 & 1 & 9 \\
\hline $\begin{array}{l}\text { Fund Manager Characteristics } \\
\text { Proportion of MBA/CFA (\%) }\end{array}$ & 80 & 64.794 & 0 & 100 & 123 \\
\hline Proportion of Legally trained manager (\%) & 3 & 8.572 & 0 & 100 & 123 \\
\hline Proportion of Ph.D (\%) & 5 & 12.751 & 0 & 100 & 123 \\
\hline Years Relevant Work Experience & 15 & 14.833 & 4 & 40 & 123 \\
\hline $\begin{array}{l}\text { Fund Characteristics } \\
\text { Funds Raised }\end{array}$ & $70,900,000$ & $144,667,817.7$ & $263,377.5$ & $930,000,000$ & 123 \\
\hline Bank Institutional Investors & 0.1 & 0.179 & 0 & 1 & 123 \\
\hline Government Investors & 0.03125 & 0.102 & 0 & 1 & 123 \\
\hline Pension Investors & 0.1 & 0.178 & 0 & 1 & 123 \\
\hline Endowment Investors & 0 & 0.054 & 0 & 0.5 & 123 \\
\hline limited Partnership Funds & 1 & 0.585 & 0 & 1 & 72 \\
\hline Industry Market/Book & 3.528 & 3.945 & 0.82 & 24.74 & 123 \\
\hline Early-stage Investee Focus & 0 & 0.309 & 0 & 1 & 38 \\
\hline
\end{tabular}


Table 4. Correlations

This table presents correlation across the variables defined in Table 1 .

\begin{tabular}{|c|c|c|c|c|c|c|c|c|c|c|c|c|c|c|c|c|c|c|c|c|c|c|c|c|c|c|}
\hline & & (1) & (2) & (3) & (4) & (5) & (6) & (7) & (8) & (9) & (10) & (11) & (12) & (13) & (14) & (15) & (16) & (17) & (18) & (19) & (20) & (21) & (22) & (23) & (24) & (25) \\
\hline (1) & $\begin{array}{l}\text { Management Fees } \\
(\%)\end{array}$ & 1.00 & & & & & & & & & & & & & & & & & & & & & & & & \\
\hline (2) & $\begin{array}{l}\text { Carried Interest } \\
(\%)\end{array}$ & -0.28 & 1.00 & & & & & & & & & & & & & & & & & & & & & & & \\
\hline (3) & Clawbacks & 0.25 & -0.09 & 1.00 & & & & & & & & & & & & & & & & & & & & & & \\
\hline (4) & $\begin{array}{l}\text { Cash } \\
\text { Distributions }\end{array}$ & -0.05 & -0.10 & 0.00 & 1.00 & & & & & & & & & & & & & & & & & & & & & \\
\hline (5) & legality Index & -0.62 & 0.51 & -0.27 & -0.16 & 1.00 & & & & & & & & & & & & & & & & & & & & \\
\hline (6) & $\begin{array}{l}\text { English Legal } \\
\text { Origin }\end{array}$ & -0.12 & -0.04 & 0.06 & -0.06 & -0.10 & 1.00 & & & & & & & & & & & & & & & & & & & \\
\hline (7) & $\begin{array}{l}\text { French Legal } \\
\text { Origin }\end{array}$ & -0.03 & 0.02 & 0.05 & 0.02 & 0.08 & -0.71 & 1.00 & & & & & & & & & & & & & & & & & & \\
\hline (8) & $\begin{array}{l}\text { German Legal } \\
\text { Origin }\end{array}$ & 0.05 & 0.11 & -0.10 & -0.09 & 0.17 & -0.26 & -0.22 & 1.00 & & & & & & & & & & & & & & & & & \\
\hline (9) & $\begin{array}{l}\text { Scandinavian } \\
\text { Legal Origin }\end{array}$ & 0.05 & 0.11 & -0.04 & 0.04 & 0.16 & -0.19 & -0.16 & -0.06 & 1.00 & & & & & & & & & & & & & & & & \\
\hline (10) & GNP per Capita & -0.42 & 0.42 & -0.21 & 0.18 & 0.75 & -0.21 & 0.06 & 0.23 & 0.20 & 1.00 & & & & & & & & & & & & & & & \\
\hline (11) & MSCI Index & 0.18 & -0.28 & -0.04 & 0.10 & -0.23 & -0.10 & -0.10 & -0.04 & -0.03 & -0.14 & 1.00 & & & & & & & & & & & & & & \\
\hline (12) & $\begin{array}{l}\text { Year of fund } \\
\text { formation }\end{array}$ & 0.03 & -0.04 & 0.08 & 0.18 & -0.14 & 0.17 & -0.29 & -0.03 & 0.15 & 0.14 & 0.17 & 1.00 & & & & & & & & & & & & & \\
\hline (13) & $\begin{array}{l}\text { Outbound } \\
\text { Offshore }\end{array}$ & -0.26 & -0.12 & -0.12 & 0.19 & 0.08 & 0.08 & -0.07 & 0.05 & 0.02 & -0.01 & -0.07 & 0.06 & 1.00 & & & & & & & & & & & & \\
\hline (14) & Inbound Offshore & 0.03 & 0.05 & 0.04 & 0.18 & -0.03 & 0.18 & -0.09 & -0.08 & -0.06 & -0.12 & 0.00 & 0.06 & 0.13 & 1.00 & & & & & & & & & & & \\
\hline (15) & $\begin{array}{l}\text { Proportion of } \\
\text { MBA }\end{array}$ & -0.01 & -0.09 & -0.10 & -0.17 & -0.09 & 0.35 & -0.38 & 0.04 & -0.03 & -0.28 & 0.12 & 0.00 & 0.12 & 0.14 & 1.00 & & & & & & & & & & \\
\hline (16) & $\begin{array}{l}\text { Proportion of } \\
\text { Ph.D }\end{array}$ & 0.17 & 0.07 & 0.21 & -0.01 & -0.11 & -0.12 & 0.18 & -0.09 & -0.05 & -0.01 & -0.03 & 0.10 & -0.22 & -0.14 & -0.19 & 1.00 & & & & & & & & & \\
\hline (17) & $\begin{array}{l}\text { Legally trained } \\
\text { Managers }\end{array}$ & 0.08 & -0.01 & 0.01 & 0.07 & -0.10 & -0.21 & 0.29 & -0.07 & -0.11 & 0.02 & -0.08 & -0.11 & -0.02 & 0.08 & -0.30 & 0.01 & 1.00 & & & & & & & & \\
\hline (18) & Work Experience & 0.06 & -0.15 & 0.02 & 0.06 & -0.05 & 0.22 & -0.19 & -0.02 & -0.05 & -0.02 & 0.12 & 0.14 & -0.09 & 0.03 & -0.08 & -0.08 & -0.02 & 1.00 & & & & & & & \\
\hline (19) & funds Raised & -0.16 & -0.02 & -0.08 & 0.19 & 0.10 & -0.14 & 0.10 & -0.02 & -0.05 & 0.16 & 0.11 & -0.04 & 0.02 & -0.04 & -0.03 & -0.12 & -0.03 & 0.12 & 1.00 & & & & & & \\
\hline (20) & Bank Investors & -0.07 & 0.12 & -0.11 & -0.04 & 0.07 & -0.27 & 0.23 & 0.22 & -0.14 & 0.09 & -0.02 & -0.20 & -0.14 & -0.13 & -0.11 & -0.11 & 0.08 & -0.01 & 0.16 & 1.00 & & & & & \\
\hline (21) & $\begin{array}{l}\text { Government } \\
\text { Investors }\end{array}$ & 0.21 & -0.12 & 0.22 & -0.10 & -0.17 & 0.11 & -0.06 & -0.07 & 0.01 & -0.30 & -0.03 & 0.07 & 0.09 & 0.08 & 0.02 & 0.17 & -0.06 & -0.09 & -0.21 & -0.22 & 1.00 & & & & \\
\hline (22) & Pension Investors & 0.03 & -0.09 & -0.06 & 0.25 & -0.04 & 0.13 & -0.11 & -0.20 & 0.03 & 0.08 & 0.14 & 0.02 & -0.13 & -0.12 & -0.08 & -0.03 & -0.02 & 0.07 & 0.09 & -0.10 & -0.21 & 1.00 & & & \\
\hline (23) & $\begin{array}{l}\text { Endowment } \\
\text { Investors }\end{array}$ & -0.11 & 0.06 & -0.04 & 0.14 & 0.21 & -0.09 & 0.07 & -0.10 & 0.26 & 0.25 & -0.07 & -0.04 & 0.15 & 0.03 & -0.14 & -0.09 & 0.03 & -0.02 & 0.13 & -0.05 & -0.13 & 0.23 & 1.00 & & \\
\hline (24) & $\begin{array}{l}\text { Limited } \\
\text { Partnership Fund }\end{array}$ & -0.13 & -0.03 & -0.07 & 0.22 & 0.11 & 0.04 & -0.10 & -0.02 & 0.09 & 0.21 & 0.08 & 0.08 & 0.15 & 0.05 & -0.08 & -0.07 & 0.06 & 0.05 & 0.04 & -0.08 & -0.14 & 0.14 & 0.21 & 1.00 & \\
\hline (25) & $\begin{array}{l}\text { Industry } \\
\text { Market/Book }\end{array}$ & 0.06 & 0.02 & 0.09 & 0.00 & -0.07 & 0.11 & -0.12 & 0.04 & 0.01 & -0.07 & -0.10 & 0.03 & 0.07 & -0.07 & 0.05 & 0.41 & -0.06 & -0.14 & -0.10 & -0.06 & 0.36 & -0.08 & -0.03 & -0.10 & 1.00 \\
\hline (26) & $\begin{array}{l}\text { Early-Stage fund } \\
\text { focus }\end{array}$ & 0.10 & 0.19 & -0.02 & 0.16 & 0.00 & -0.05 & -0.04 & 0.08 & 0.04 & 0.11 & -0.08 & 0.07 & 0.04 & -0.12 & -0.13 & 0.15 & 0.05 & -0.17 & -0.01 & 0.12 & -0.06 & -0.07 & 0.03 & 0.06 & 0.13 \\
\hline
\end{tabular}


Table 5. Regression Analyses of Management Fees

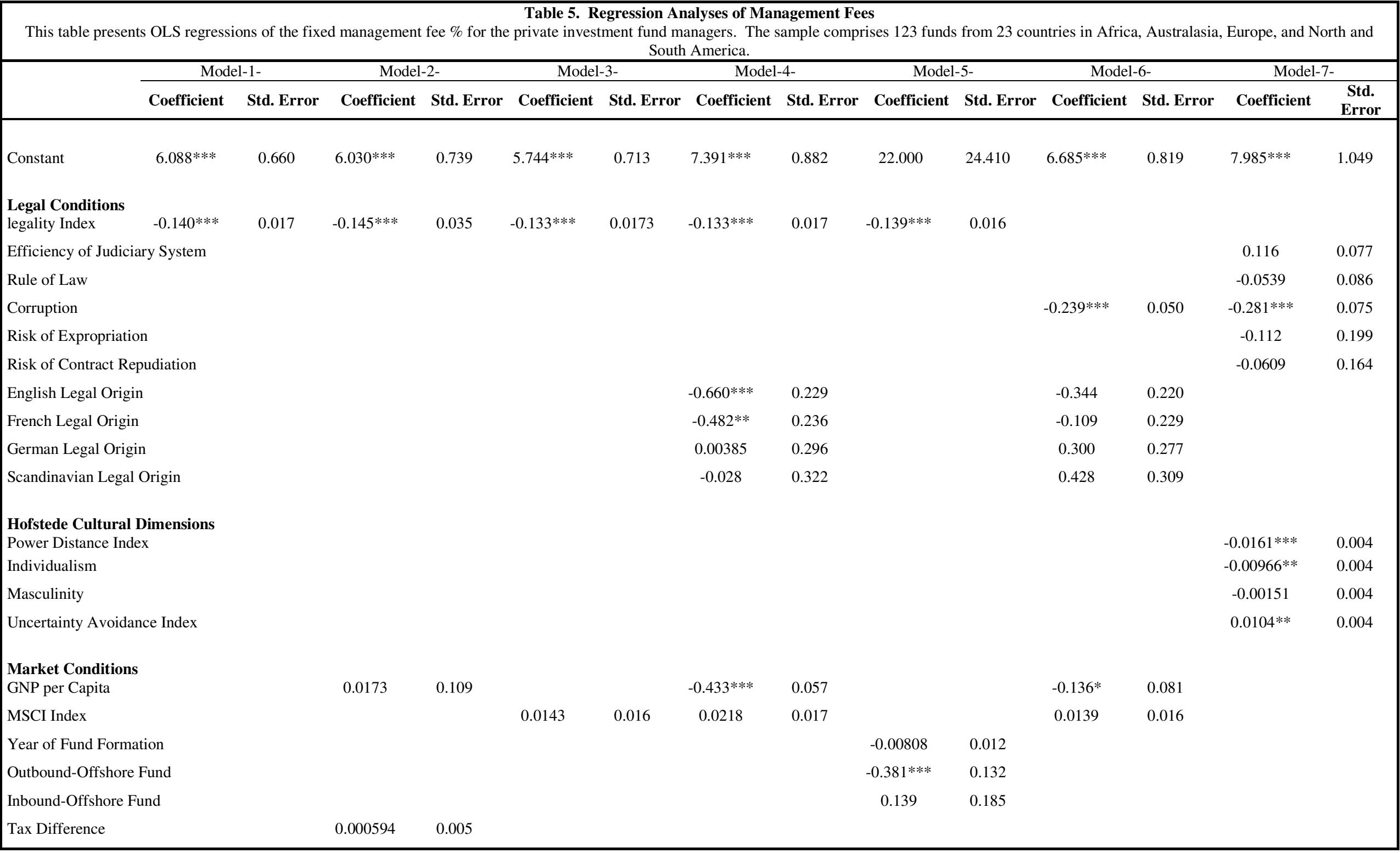




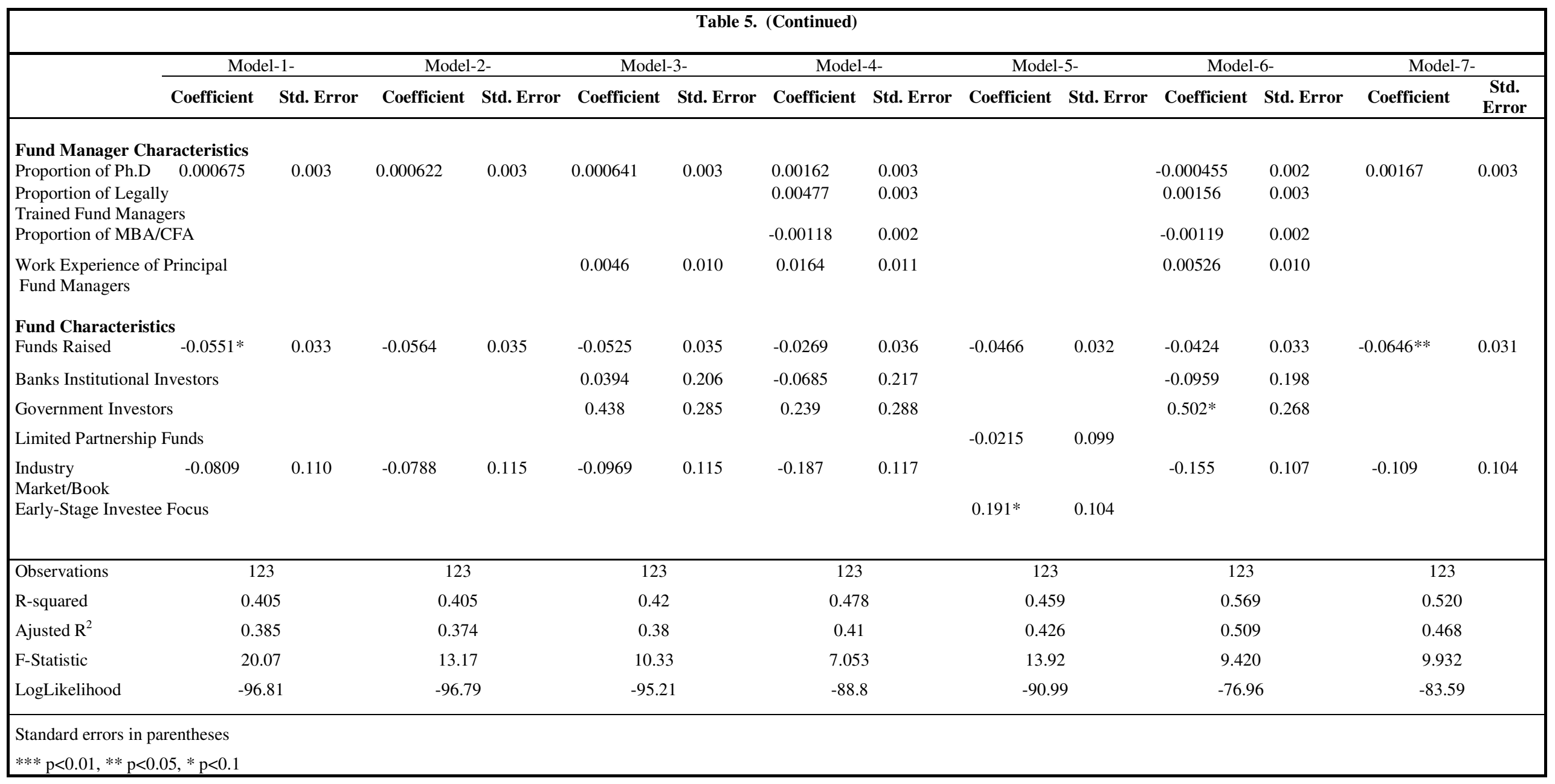


Table 6. Regression Analyses of Carried Interest

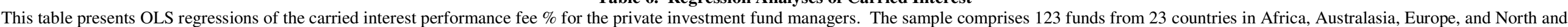
South America.

\begin{tabular}{|c|c|c|c|c|c|c|c|c|c|c|c|c|c|c|}
\hline & \multicolumn{2}{|c|}{ Model -8- } & \multicolumn{2}{|c|}{ Model -9- } & \multicolumn{2}{|c|}{ Model -10- } & \multicolumn{2}{|c|}{ Model -11- } & \multicolumn{2}{|c|}{ Model -12- } & \multicolumn{2}{|c|}{ Model -13- } & \multicolumn{2}{|c|}{ Model -14- } \\
\hline & Coefficient & $\begin{array}{c}\text { Std. } \\
\text { Error }\end{array}$ & Coefficient & $\begin{array}{c}\text { Std. } \\
\text { Error }\end{array}$ & Coefficient & $\begin{array}{c}\text { Std. } \\
\text { Error }\end{array}$ & Coefficient & $\begin{array}{c}\text { Std. } \\
\text { Error }\end{array}$ & Coefficient & $\begin{array}{l}\text { Std. } \\
\text { Error }\end{array}$ & Coefficient & Std. Error & Coefficient & Std. Error \\
\hline Constant & $9.083 * * *$ & 3.366 & $9.063 * *$ & 3.836 & $11.46 * * *$ & 3.707 & $11.77 * *$ & 5.309 & -36.31 & 126.800 & 5.243 & 4.983 & $-8.684 *$ & 4.873 \\
\hline $\begin{array}{l}\text { Legal Conditions } \\
\text { legality Index }\end{array}$ & $0.563 * * *$ & 0.087 & $0.550 * * *$ & 0.179 & $0.568 * * *$ & 0.090 & $0.680 * * *$ & 0.249 & $0.591 * * *$ & 0.085 & & & & \\
\hline Efficiency of Judiciary System & & & & & & & & & & & & & $1.915 * * *$ & 0.358 \\
\hline Rule of Law & & & & & & & & & & & & & $-0.945 * *$ & 0.398 \\
\hline Corruption & & & & & & & & & & & 0.00346 & 0.306 & $-0.752 * *$ & 0.346 \\
\hline Risk of Expropriation & & & & & & & & & & & & & 0.932 & 0.924 \\
\hline Risk of Contract Repudiation & & & & & & & & & & & & & $1.677 * *$ & 0.760 \\
\hline English Legal Origin & & & & & & & 0.933 & 1.366 & & & $2.536^{*}$ & 1.337 & & \\
\hline French Legal Origin & & & & & & & -0.130 & 1.386 & & & 1.389 & 1.396 & & \\
\hline German Legal Origin & & & & & & & 0.648 & 1.658 & & & 1.948 & 1.685 & & \\
\hline Scandinavian Legal Origin & & & & & & & 0.969 & 1.872 & & & 2.900 & 1.883 & & \\
\hline $\begin{array}{l}\text { Hofstede Cultural Dimensions } \\
\text { Power Distance Index }\end{array}$ & & & & & & & & & & & & & 0.0208 & 0.020 \\
\hline Individualism & & & & & & & & & & & & & -0.0328 & 0.021 \\
\hline Masculinity & & & & & & & & & & & & & -0.000426 & 0.018 \\
\hline Uncertainty Avoidance Index & & & & & & & & & & & & & $0.0691 * * *$ & 0.019 \\
\hline $\begin{array}{l}\text { Market Conditions } \\
\text { GNP per Capita }\end{array}$ & & & 0.134 & 0.563 & & & -0.379 & 0.776 & & & $1.564 * * *$ & 0.494 & & \\
\hline $\begin{array}{l}\text { MSCI Index } \\
\text { Year of Fund Formation }\end{array}$ & & & & & 0.117 & 0.082 & 0.111 & 0.101 & 0.0222 & 0.063 & -0.00204 & 0.096 & & \\
\hline Outbound-Offshore Fund & & & & & & & & & $-1.558 * *$ & 0.684 & & & & \\
\hline Inbound-Offshore Fund & & & & & & & & & -1.468 & 0.962 & & & & \\
\hline Tax Difference & & & $-0.0531 *$ & 0.027 & & & & & & & & & & \\
\hline
\end{tabular}




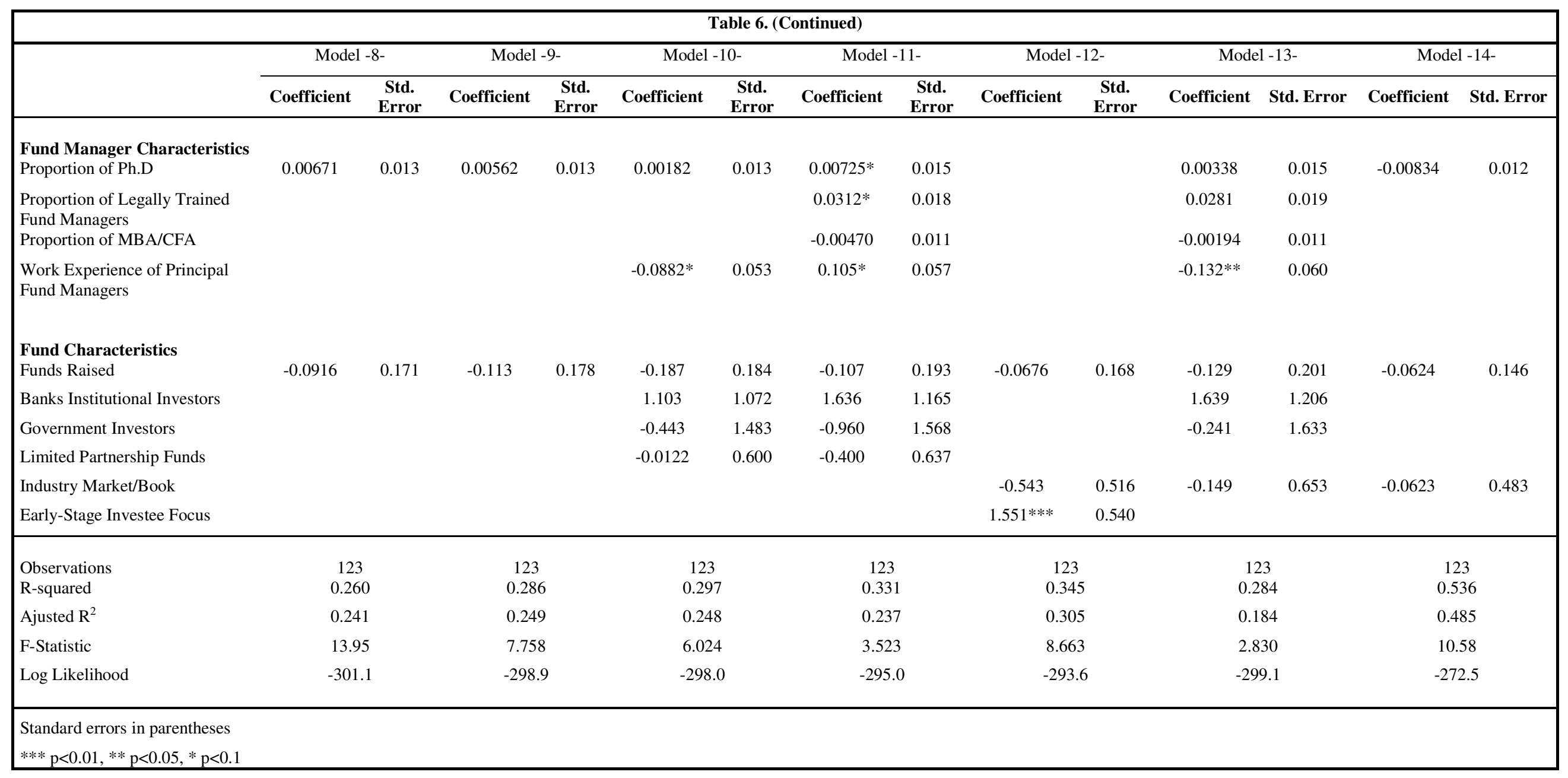


Table 7. Regression Analyses of Clawbacks against Fund Managers

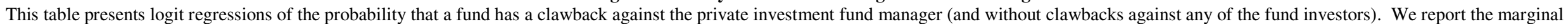

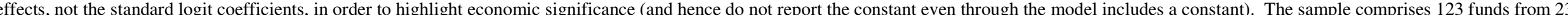

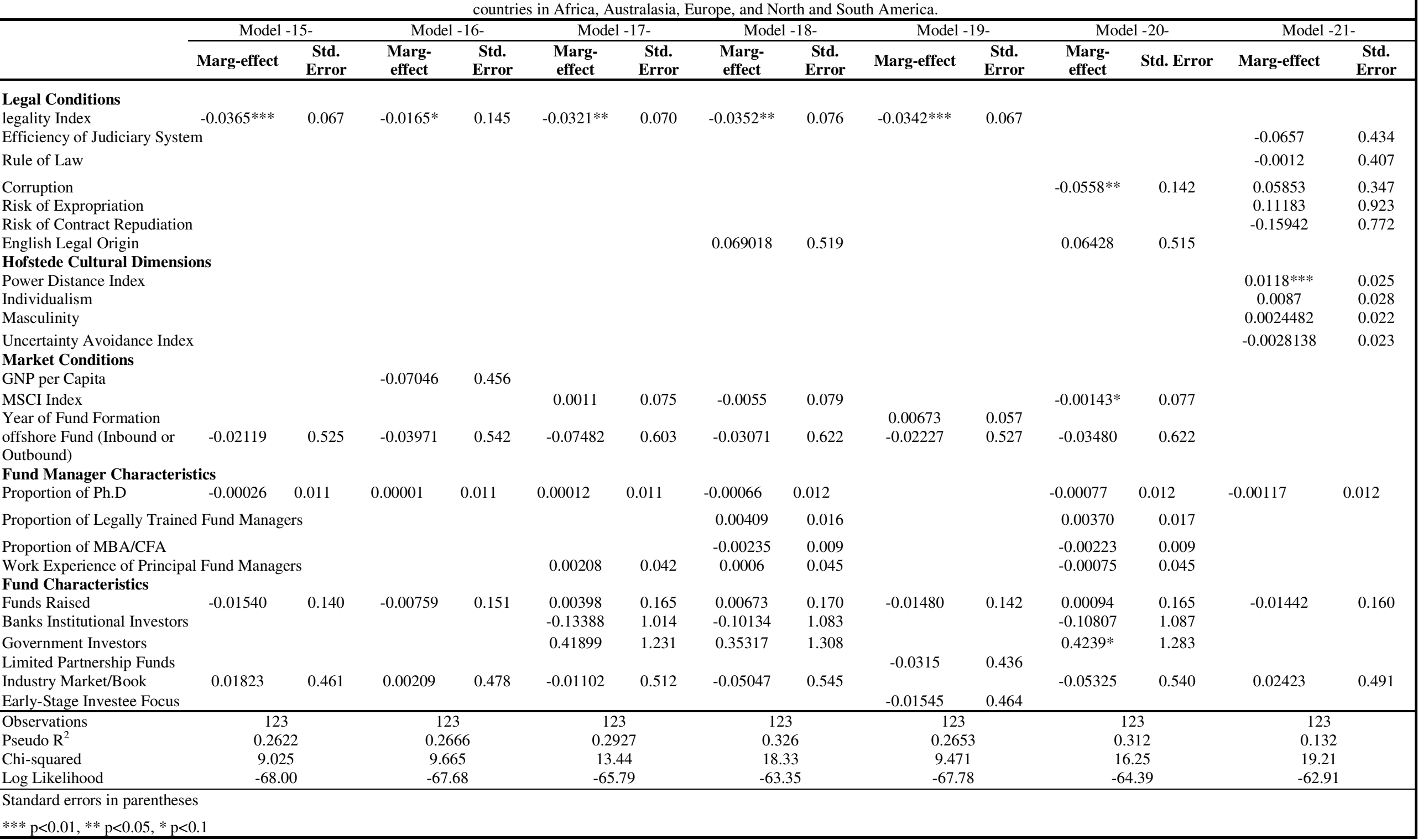


Table 8. Regression Analyses of Cash versus Share Distributions

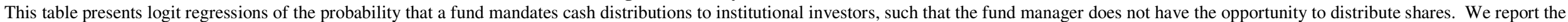

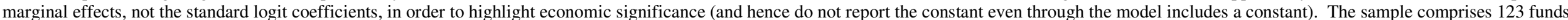

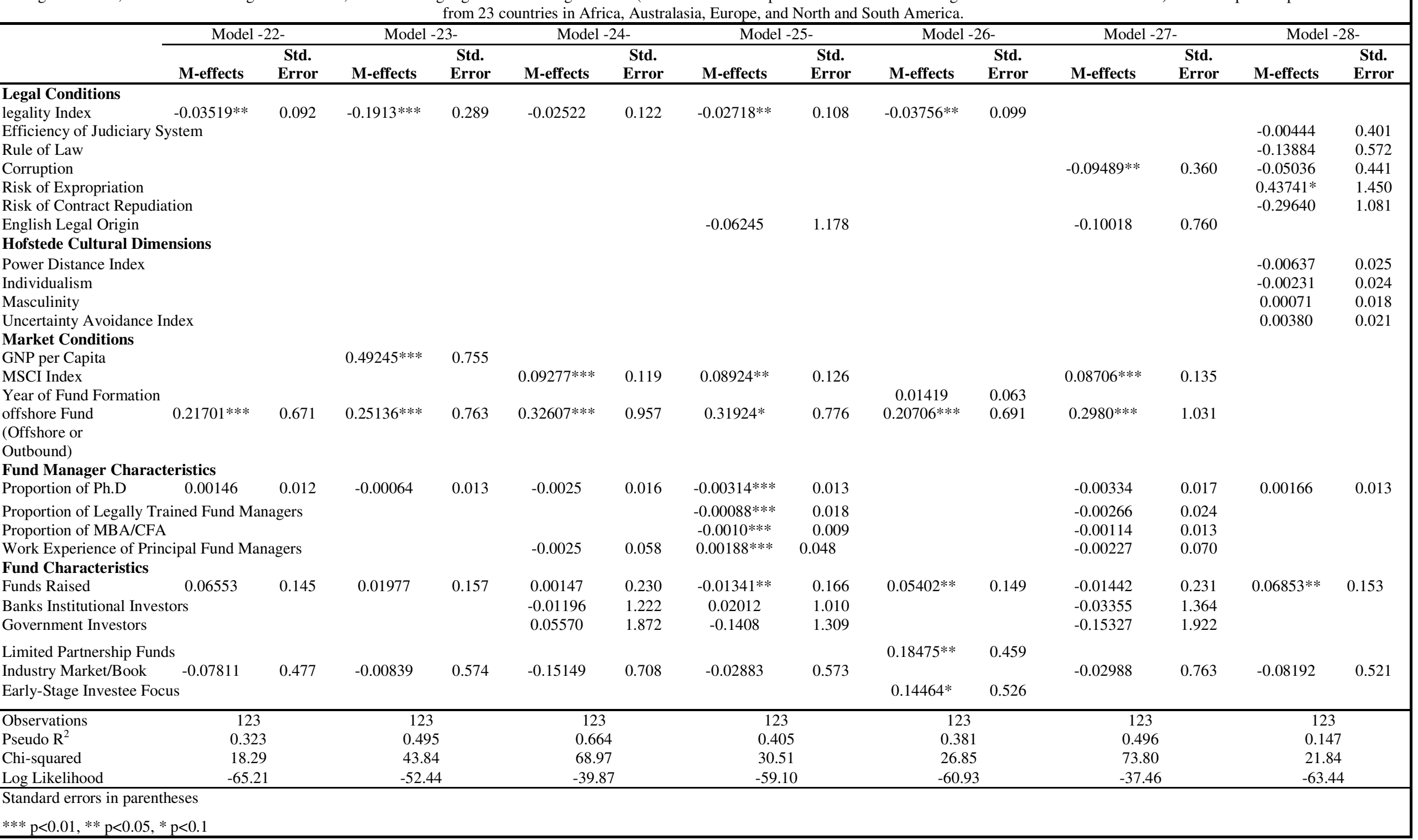

